\title{
16-18. Asırlarda Buhara Hanlığı'na Gelen Batılı Seyyahlar ve Seyahatnameleri
}

\author{
Selim Serkan ÜKTEN ${ }^{*}$
}

\author{
16-18. Asırlarda Buhara Hanlığı'na Gelen Batılı Seyyahlar \\ ve Seyahatnameleri
}

Özet

Tarihte Türk dünyasının en önemli kültür ve medeniyet sahalarından biri olarak karşımıza çıkan Batı Türkistan, sahip olduğu coğrafyanın sunduğu imkânlar sebebiyle de pek çok milletin ilgi alanında olmuştur. Özellikle Orta Çağ’ın sonundan itibaren yükselişe geçen Avrupa toplumu bölgeyi tanımak adına bazı girişimlerde bulunmuştur. 16. asrın ikinci yarısından sonra ise Doğu Avrupa'da yükselişe geçen Rusya, yakınında bulunan bölgeyi uzun vadede kontrol etmeyi düşünmüş ve bu amaçla bölgenin merkez hanlı̆ı durumundaki Buhara Hanlığ'na pek çok devlet görevlisi göndererek, bölgeyi tanımaya çalışmıştır. Bu seyahatlerin sonunda bölgede bulunan hanlıklar ve Türkistan coğrafyası hakkında çok değerli bilgiler veren seyahat notları ortaya çıkmıştır. Bu çalışmada söz konusu hanlığı 16-18. asırlarda ziyaret eden, çoğunluğunu Rusların oluşturduğu batılı seyyahlar, onlardan geriye kalan seyahat notları ve notların nitelikleri incelenmiştir.

Anahtar Kelimeler: Seyahatname, Batı Türkistan, Buhara Hanlığı, Elçi, Ticaret

\section{Giriş}

Seyahatnameler bir devletin veya toplumun siyasi, sosyal, kültürel, iktisadi yapısı hakkında vermiş olduğu bilgilerle tarihi kaynaklar arasından mühim bir yer tutmaktadır. Her ne kadar bir tarihi materyal olarak seyyahın ön yargılarını veya öznel düşüncelerini içerdikleri düşünülerek, kronik, hatırat veya arşiv belgelerine nazaran fazla güvenilir kaynaklar olmadıkları üzerine yorumlar olsa da, bazen bir seyahat notunun güvenilirliği farklı meselelerden dolayı rakip bir devlet hakkında

* Selim Serkan ÜKTEN, Yrd.Doç.Dr., Aksaray Üniversitesi, Tarih Bölümü, sserkanukten@gmail.com

\author{
Western Travellers and Their Travel Books on Khanate \\ of Bukhara between 16-18 Centuries
}

Abstract

Throughout history, we see Western Turkestan as one of the most important cultural and civilization regions of the Turkish world, and was at the center of many nations' interest owing to opportunities provided by its geography. As European society made attempts at familiarizing with the region. Russia, which was on the rise in Eastern Europe from second half of 16. Century, planned to control the adjacent region in the long run and for this purpose sent many officials to the Khanate of Bukhara, which was region's principal khanate, in order to cognize with the region. As a result of these journeys, travel notes emerged containing invaluable information on region's Khanates and Turkestan's geography. In this work Western travelers, majority of whom were Russians, who visited the aforementioned khanate in 16-18. Centuries, travel notes left by said travelers and properties of these notes will be examined.

Key Words: Travel Book, West Turkestan, Khanate of Bukhara, Ambassador, Trade started to rise, especially from the end of the Medieval Period, it 
önyargıları bulunan bir vakanüvisin kaleminden çıkan bir eserin güvenilirliğinden aşağıda değildir. Tarihi kaynakların her bir türüne bakıldığında, bunların hepsinde genel bir güvenilirlik problemi olduğunu kabul etmemiz gerekir. Buradaki sorun elbette ki bir konu üzerine yapılan çalışmada kaynak çeşitliliğini artırarak, kaynakları karşılaştırarak ve olayları doğru analiz ederek çözülebilecektir.

Seyahatnamelerin güvenilirliği üzerine yapılan tartışmalar bir yana, bunların birer kaynak olarak en önemli özelliği, bir toplumun kendi yaşamında sıradan karşılayarak göz ardı ettiği en ince detayları içermesidir. Zeki Velidi Togan'ın da üzerinde durduğu üzere bir yabancı seyyah daima bizim dikkat etmediğimiz hususları gözlemlemiştir (Togan, 1969, s. 59). Seyyahlar yerli veya yabancı olabilirler. Bir devlet veya toplum hakkında bilgi veren yabancı bir seyyahın gözlemleri ise daha dikkat çekicidir. Yabancı seyyahlar başka bir coğrafyaya çeşitli nedenlerden dolayı seyahat ederek seyahat notları alabilir. Bu, bazen bir şahsın bireysel olarak yaptığı gezide aldığı notlardan ibaret olabilir. Fakat bazı seyahat notları vardır ki, bunlar, belli bir amaç için görevlendirilen devlet adamlarının, elçi, tacir, asker veya din adamı sıfatıyla yapmış oldukları gezilerde, başta siyasi, askeri ve coğrafi olmak üzere, pek çok konudaki gözlemlerini içerir. Bu notlar çoğu kez gizlice tutulurken, oluşan belge veya raporların bir bütün olarak kitaplaştırılması, yani seyahatname haline gelmesi görevlilerin misyonlarını tamamlamalarından çok sonra olabilir. İşte bu tarz seyahat notları veya raporları tarihi kaynaklar olarak oldukça zengin bilgileri ihtiva etmelerinin yanı sıra güvenilir de kaynaklardır. Zira bir casusun ülkesi adına toplayacağı bilgilerin gerçekçi olması son derece önemlidir. Bununla birlikte seyyahın özellikle gözlemlediği toplumun kültürüne ve inanışlarına dair bazı önyargıları veya bölgenin diline hâkim olmamasından dolayı bazı kelimeleri yanlış yazması söz konusu olabilir ki, bunlar detaylı araştırmalarla çözülebilecek problemlerdir.

Seyahatnameler, Orta Asya Türk tarihi araştırmaları için oldukça önemlidir. İlk Çağ’dan itibaren Uzak Doğu'da Çin, Batı'da Avrupa ve İslamiyet'le birlikte yükselişe geçen Araplar çeşitli vesilelerle gerçekleştirdikleri gezilerde, Bozkır Türk yurdu ve Türk halkını tasvir eden birbirinden değerli yazılı eserler bırakmışlardır. Özellikle Orta Çağ’ın erken döneminde Arap ve Çinli gezgin veya elçilerin Türkler hakkında vermiş olduğu bilgilerin fazlalı̆̆ı dikkat çekicidir. Fakat Geç Orta Çağ’da Haçlı seferleri ile başlayan süreçte, Doğu hakkındaki bilgileri artık yükselişe geçen Avrupa verecektir. Avrupa'nın Doğu'ya dini ve ekonomik sebeplerle başlayan ilgisi bu dönemde daha ziyade Orta Doğu toplumu hakkında bilgi sahibi olmasını sağlamıştır. Fakat erken Haçlı seferlerinin akabinde gerçekleşen Moğol istilası, Avrupa'nın dikkatini bu kez tehlikenin geldiği Avrupa'nın doğusu ve buranın ötesinde Asya'nın derinliklerine kadar uzanan topraklara çekmiştir. Bu süreçle beraber Doğu'ya yönelen misyonerler, elçiler ve tacirler, Orta Asya Türk ve Moğol tarihi adına çok değerli bilgiler içeren seyahatnamelerin oluşmasını sağlamışlardır.

Başlarda olası bir Moğol istilasının kıtayı etkilemesinden korkan Avrupa hanedanları düşmana karşı birlik olmayı başaramamıştır. Fakat bir süre sonra 1245'te Lyon'da Papa IV. Innocent tarafından toplanan konsülde Moğol meselesi ciddi bir şekilde masaya yatırılmış ve ruhaniler, Moğolları durdurmanın yolu olarak çareyi onları misyonerler aracilığıla Hristiyanlığa çekmekte ve Hristiyan 
kanı dökmemeleri için ricada bulunmakta bulmuşlardı. Bu amaç doğrultusunda misyonerlerden oluşan bir elçilik heyeti hazırlanarak rahip Jean du Plan Carpin liderliğinde 1245'te Moğollara gönderildi. Elçilik asıl amaçları dışında Moğol ülkesini, halkını ve geleneklerini tanıyabilmek için de gözlemlerde bulunacaktı. Doğu Avrupa'dan Moğolistan'a kadar geniş bir coğrafyada hareket imkânı bulan Carpin, Hristiyan dünyasını memnun edecek görevi başaramadığı seyahatinin sonunda, gözlemlerini içeren Latince bir eser bırakmıştır. Carpin'in eseri Orta Çağ’da Türk ve Moğol toplulukları adına kıymetli bilgiler içermektedir. Seyahat notlarında Moğolların hâkim olduğu coğrafyanın yanı sıra, Moğol ve Türk halklarının dinleri, hukukları, gelenek ve görenekleri, savaş usulleri ve diğer uluslara karşı tavırları üzerine de izlenimler bulunmaktadır (D’ohsson, 2014, s. 217; Türker ve Ükten, 2014, s. 336; Barthold, 2004, s. 119; Plano Carpini'nin Moğolistan Seyahatnamesi, 2015, s. 10). Carpin'in görevinin başarısızıkla sonuçlanmasından sonra Batı-Moğol münasebetleri hemen sona ermiş değildir. Moğolların, İslam dünyasına karşı Haçlılarla birlikte hareket etmek istedikleri söylentileri ve Avrupalıların misyonerlik faaliyetlerine devam etme düşünceleri, bu kez Fransa kralı IX. Louis'in girişimleriyle Rubroucklu William'ın Doğu'ya hareket etmesine olanak sağlamıştı. Bir HaçlıMoğol ittifakı kurmak ve Moğollara Hristiyanlığı öğretmekle görevlendirilen William, aşağı yukarı Carpin'in güzergâhını takip ederek vardığı Moğol yurdunda, Moğolların örf ve adetleri, bunun yanı sıra Moğol İmparatorluğu çatısı altındaki Türk halklarının din ve kültürleri hakkında topladığı değerli bilgileri raporlarına eklemiştir (1253-1255) (Ruysbroeckli Willem, 2010, s. 48-68; Barthold, 2004, s. 120-121). 13. asrın ortalarında Avrupalıların Doğu dünyasını tanıma süreçleri Polo ailesi vasıtasıyla devam etmiştir. İlk kez Niccolo ve Matteo Polo kardeşlerin Kubilay Han'ın sarayı Pekin'e yaptıkları seyahatin ikincisi, bu defa Niccolo'nun oğlu Marco Polo'nun da bulunduğu aile üyeleri tarafından 1271 'de gerçekleştirilmiştir. Poloların uzun yıllar geçirdikleri Kubilay Han'ın ülkesi Çin başta olmak üzere, Türk ve Moğol coğrafyası hakkındaki izlenimleri, daha sonra Marco Polo tarafından yazıya dökülmüştür. Avrupa'yı Uzak Doğu'nun zenginliklerinden haberdar ederek, kıtanın geleceğini etkilemiş bu çok önemli eser, seyyahın Orta Asya hakkında verdiği bilgilerle de büyük bir öneme sahiptir (Marco Polo'nun Geziler Kitabı, 2015, s. 5-6; Barthold, 2004, s. 123-126).

Avrupalıların Doğu'ya olan ilgisi sonraki asırlarda da devam etmiştir. Orta Çağ'ın sonlarına yaklaşıldığı 15. asrın hemen başlarında İspanyol elçi Clavijo'nun Timur'un devletine seyahati, Avrupalıların "Batı Türkistan" hakkındaki ilk detaylı bilgileri vereceği seyahatnamenin oluşmasını sağlamıştır. 1402 Ankara Savaşı'ndan sonra başlayan Avrupa-Timur yakınlaşmasının bir sonucu olan bu elçilik görevinde Clavijo, yolculuğuna 1403'te Kadis'ten başlamış ve Anadolu, Azerbaycan, İran ve Horasan güzergâhını kullanarak Timur'un payitahtı Semerkand'a varmıştır. Seyahati boyunca yaptığı gözlemleri ise İspanya'ya döndükten sonra bir eser haline getirmiştir. Clavijo seyahatnamesi, Timurlu Devleti adına vermiş olduğu bilgilerle önemli bir ana kaynak durumundadır. Devlet geleneği, teşkilatlanma, hukuk, saray merasimleri hakkındaki bilgilerin yanı sıra, Timur'un mizacı ve son zamanları hakkında da değerli bilgiler eserde mevcuttur. Eser bunun yanı sıra Horasan ve Türkistan şehir tarihi için de önemli bilgiler içermektedir. Başta Semerkand olmak üzere Buhara, Keş gibi Maveraünnehr'in önemli merkezleri seyyah tarafından ayrıntılı bir şekilde incelenmiştir (Clavijo, 2016, s. 139-249; Barthold, 2004, s. 135-137). 
16. asrın başlarında Avrupalıların Orta Asya'ya ilgileri giderek azalmaya başlamıştır. Asya’nın derinliklerinden gelen Moğol gücünün sönmesinin yanı sıra, coğrafi keşiflerle birlikte ticaret yollarının karadan denize kayması, yükselen Avrupa'nın ilgisini deniz yolu vasıtasıyla Marco Polo'nun bahsettiği Çin'in hatta Hindistan'ın zenginliklerine çekmiştir. Ticaret için Ön Asya artık ikincil bir önem arz ediyor, diğer taraftan Akdeniz'i bir Türk gölü haline getiren Osmanlılara karşı, onların doğudaki rakipleri İran'a bir sempati besleniyordu. Kısacası Avrupalıların Doğu'ya ilgileri Levant bölgesi, İran, Hindistan ve daha ötede Uzakdoğu ile sınırı kalırken, Orta Asya artık tüccar, misyoner ve seyyahların uğramadığı bir bölge haline geliyordu. Orta Asya adına farklılık yaratacak bir girişim mezkûr asrın ortalarında denizcilikte önemli bir mesafe kat eden İngilizlerden geldi. Amaçları Çin'e gitmek için daha farklı yollar keşfetmek olan İngilizler, Ruslarla bir anlaşma yaparak Orta Asya'dan geçmek suretiyle Rusya'dan Çin'e giden ticaret yollarından faydalanmayı düşündüler (Barthold, 2004, s. 165-171). Bu düşünce sonucunda aşağıda bahsedeceğimiz İngiliz tacir Jenkinson, yeni ticaret yolları keşfetmek için Maveraünnehr'in kalbi Buhara'ya kadar seyahat etmiştir. Fakat bu girişimle Orta Asya'daki büyük düşüşü fark eden İngilizler, Hindistan'ın bütününü müstemleke haline getirecekleri 19. asra kadar bölgeye uğramamışlardır.

Yeni Çağ’dan itibaren bölgeden uzaklaşan Avrupalıların yerini Orta Asya'ya ilgileri asla azalmayacak bir güç olarak artık Ruslar alacaktır. Rurik hanedanının son büyük hükümdarı IV. İvan zamanında giderek güçlenerek 1552 Kazan'ı ve 1556 Astrahan'ı ele geçiren Ruslar, uzun dönem gölgesinde kaldığı Türk-Tatarlar gücünü kırmanın ötesinde, artık gözünü bu halkların yaşadığı geniş Asya bozkırlarına dikmiştir. Coğrafi keşifler ve ateşli silahların keşfiyle başlayan Batı'nın Doğu toplumuna üstünlügünü Türkistan coğrafyası adına Rusya gösterecektir ${ }^{1}$ ve bu süreç 17. asrın başlarında Romanov hanedanının Rusya'da iktidara gelmesiyle (1613) giderek hızlanacaktır. Rusların geniş Asya steplerinde ilk siyasi muhatapları ise Hazarın ötesinde Batı Türkistan hanlıkları olacaktır.

Romanovlar 17. asır boyunca başta ticari ilişkileri geliştirmek ve Türkmenlerin Hazar çevresinde esir alarak Türkistan Hanlıklarına sattığı Rus vatandaşlarını kurtarmak gibi çeşitli sebeplerle Türkistan'a elçiler göndermiştir. Fakat ortaya çıkan elçilik raporlarının geneli incelendiğinde, yapılan gezilerin coğrafyayı ve rakip devletleri tanımaya yönelik bilgiler içerdiği de görülmektedir. 18. asırda Çar Büyük Petro ile başlayan süreçte ise Türkistan'a gönderilen elçiler artık Orta Asya'nın nasıl ele geçirilebileceğiyle alakalı bilgiler de toplamaya başlamışlardır². Zira Rusların yeni çarı, Amu Derya Nehri vasıtasıyla Hindistan ve Hazar Denizi ticaret yolunu canlandırma ve Hindistan'ın kuzeyinde var olduğunu düşündüğü altın kaynaklarını elde etme gayesiyle hanlıkları aradan çıkarmayı dü-

\footnotetext{
${ }^{1}$ Yeni Çağ ile başlayan Orta Asya'nın düşüşü için bkz. (Golden, 2015, s. 182; Togan, 1942, s. 112-122)

2 18. asrın ilk çeyreğinde Çar Petro tarafından görevlendirilen F. Beneveni'nin faaliyet raporları incelendiğinde, Türkistan Hanlıklarının ne kadar sürede ve kaç askerle ele geçirilebileceğine dair bilgiler göze çarpmaktadır (Beneveni, 1986, s. 131-133).
} 
şünmüştür (Barthold, 2004, s. 287). Türkistan'ı ele geçirme siyaseti Petro'dan diğer Rus çarlarına kalacak bir miras olurken, 1803'te İngilizlerin Hindistan'a kesin olarak yerleşmesi, bölge adına yeni bir süreci başlatmıştır. Artık iki büyük güç arasında tampon bir bölge haline gelen Türkistan, 19. asrın başlarından itibaren adeta Rus ve İngiliz casusların akınına uğramıştır. Çoğunlukla diplomatik seyahatler görünümünde olan bu keşif gezileri, Rusların Türkistan'ı peyderpey işgal edeceği 19. asrın ortalarına kadar belirli aralıklarla devam etmiştir. 16-19. asırlar boyunca gerçekleşen bu seyahatlerden arta kalan notlar, Türkistan Hanlıkları tarihi çalışmaları adına çok kıymetli bilgiler içermektedir.

Diplomat, tacir veya askerlerin Batı Türkistan'a seyahatleri bu periyotta haliyle Buhara, Hive, Hokand ve Kazak Hanlıklarını kapsamıştır. Fakat bu hanlıklar arasında Batı'nın en çok dikkatini çeken, kuşkusuz Buhara Hanlığı olmuştur. Bu durum, adı geçen hanlığın Muhammed Şibani Han tarafından kurulan Özbek Hanlığı'nın mirasçısı ve konumu itibariyle de Türkistan'ın önemli merkezlerine sahip olmasından kaynaklanmaktadır ${ }^{3}$. Bu çalışmada resmi veya sivil halde bölgeye yönelen Batılı seyyahların, 1500-1868 yılları arasında bağımsız olarak varlığını sürdüren ve bu zaman aralığında Şibaniler, Astrahanlılar ve Mangıt Hanedanları tarafından yönetilen Buhara Hanlı̆̆ı'na yapmış oldukları geziler ve ortaya çıkardıkları seyahat notları ayrıntıya girilerek incelenmiştir. Çalışmada ele alınan seyahat notları bölgeye daha ziyade Rusların geldiği 16-18. asırlarla sınılandırılmıştır. Ruslarla birlikte İngiliz casusların da Türkistan'da görünmeye başlamasıyla, sayıları önceki asırlardakilere nazaran oldukça artmış olan 19. asır seyahatnamelerinin ise, muhtevalarının da yoğunluk arz etmesinden ötürü başka bir çalışmada incelenmeleri daha uygun olacaktır.

\section{16. Asırda Buhara Hanlığı'na Gelen Batılı Seyyahlar ve Seyahat Notları}

\subsection{A. Jenkinson:}

16. asırda Orta Asya hakkında ilk önemli bilgileri bizlere ulaştıran seyyah olarak, İngiliz A. Jenkinson, karşımıza çıkmaktadır. Bir İngiliz seyyahın bu zaman diliminde Orta Asya coğrafyasında bulunmasının temelinde ise yukarıda da bahsettiğimiz üzere İngilizlerin bölgedeki ticaret ağına dâhil olma istekleri yatmaktadır. 16. asırla birlikte deniz ticaretinde giderek gelişim gösteren İngilizler, Çin'e giden yeni ticaret yolları bulmak için girişimlere başladıktan bir süre sonra öncelikle Rusya ile ticari ilişkileri geliştirmek adına bir şirket kurmuşlardır. Amaçları Çin ve Rusya ticaret yolunu birbirine bağlayan ve Orta Çağ'da büyük bir önemi olan Orta Asya ticaret yolundan faydalanmak olan İngilizler, bu şirket vasıtasıyla Orta Asya'yı daha yakından tanımak için keşif çalışmalarına başlamıştır. 1558'de İngilizler adına şirketin temsilcisi olarak Moskova'ya gelen A. Jenkinson, burada Çar IV. İvan'ın (1547-1584) yönlendirmesiyle aynı yıl araştırmalar yapmak üzere Orta Asya'ya hareket etmiştir. Astrahan'dan yola çıkan ve Hazar Denizi'nden geçerek Mangışlak yarımadasına varan Jenkinson, ticari bir kervan ile önce Hive, sonrasında nihayet Buhara'ya ulaşmış ve 1559 'da tekrar Moskova'ya dönmüştür. Jenkinson keşif gezisi boyunca, Barthold'un da üzerinde durduğu

\footnotetext{
${ }^{3}$ Osmanlı Devleti de Türkistan ile münasebetlerinde daha ziyade Buhara Hanlığı’nı muhatap almıştır.
} 
üzere Orta Asya'daki gerilemeyi gözlemlemiş ve bölgenin Çin'le yaptığı ticaretin artık sönmeye yüz tuttuğuna kanaat getirmiştir. Nitekim İngilizler Hindistan'a yerleşmelerine kadar, bir daha Orta Asya'ya gitme teşebbüsünde bulunmamışlardır (Barthold, 2004, s. 171).

Jenkinson'un gezisi her ne kadar daha çok bölgeye sonradan gidecek Ingiliz seyyahlarına yol seçmek için yapılmış ve ortaya çıkan raporlar doğrudan Buhara Hanlığı üzerine hazırlanmamış bir evrak niteliğinde olsa da (Sela, 2013, s. 73), seyyahın verdiği sınırlı bilgiler Buhara Hanlı̆ı'nın ilk dönemlerini anlatan ilk seyahatname örneği olması bakımından hanlık tarihi çalışmaları adına önem arz etmektedir.

Jenkinson'un Buhara'ya geldiği tarihler, aslında Buhara Hanlığı'nda siyasi birliğin bozulduğu, Şibani Hanedanı (1500-1599) hanlarının birbirine üstünlük sağlayarak büyük han olma idealiyle hareket ettikleri bir dönemdir. Bu haliyle askeri harekâtın ülkeyi kasıp kavurduğu bir süre zarfında, şehirlerin ve iktisadi hayatın büyük zarar gördüğüne şüphe yoktur. Miyankal ve Kermine bölgesinin hâkimi II. Abdullah Han (büyük han olarak 1583-1598 tarihleri arasında Buhara Hanlığı tahtındadır), Jenkinson'un Buhara'ya gelmesinden henüz bir yıl öncesinde, şehrin hâkimi Burhan Sultan'ı mağlup ederek Buhara'yı ele geçirmiştir. Hanlığın tekrar siyasi bütünlüğünü sağlayabilmesi için ise Buhara ve çevresine hâkim olan Abdullah Han ile Teşkent ve çevresinin hâkimi Nevruz Ahmet Han'ın karşı karşıya gelmesi gerekecektir (bkz. Alpargu, 2002, s. 563). İşte tam da böyle karmaşık bir dönemde Buhara'ya gelen Jenkinson'un doğal olarak Buhara Hanlığı, Buhara şehri ve bölgedeki ticari yolların asayişi hakkındaki izlenimleri pek de olumlu olmamıştır.

Öncelikle Buhara şehrinin genel yapısı üzerine izlenimlerde bulunan seyyah, genel olarak kerpiçten inşa edilmiş şehrin ortasından küçük bir çay geçtiğini, fakat buradan sağlanan suyun içmek için pek de sağlıklı olmadığını, suyun vücutta yılanbalığı uzunluğunda bir solucanın oluşmasına sebep olduğunu anlatmaktadır. Buradan anlaşılıyor ki "rişta" adı verilen ve 19. asırda dahi seyyahların haber verdiği bu müzmin hastalık Buharalıların en muzdarip olduğu sağlık sorunlarının başında gelmektedir. (Jenkinson, 1886, s. 83).

Siyasi hayatta ise dönemin gelişmelerine şahit olan seyyahın vermiş olduğu bilgiler, dönemin vakayinamelerinde anlatılanlardan farklı değildir. Şehirdeki din adamının en önemli şahsiyet olduğundan bahseden Jenkinson, ona hükümdardan bile daha çok itaat edildiğini, bir önceki hükümdarın da onunla ters düşmesinden dolayı katledildiğini notlarına eklemiştir (Jenkinson, 1886, s. 83-84). Jenkinson'un burada bahsettiği eski hükümdar Burhan Sultan ve büyük din adamı olarak bahsettiği kişi ise Cuybar şeyhi Hoca İslam'dır. Dönemin Buhara'sındaki en önemli tarikat olarak karşımıza çıkan Cuybarilerin, o dönemde siyasi hayatta da oldukça etkili bir tarikat olduğu dönemin yerli kaynaklarınca da malumdur. II. Abdullah Han da, Hoca İslam'ın desteği sayesinde büyük hanlığa giden yolda mücadeleleri kazanmıştır.

Buhara'nın gelirleri hakkında verilen bilgilere göre ise, ülkenin gelirleri az, Han da yeterince zengin değildir. Devletin başılıca gelir kaynağı esnaftan alınan 1/10 oranındaki vergilerdir. Seyyah hanın gerekirse bu vergiyi zorla elde ettiğini de vurgulamaktadır. Ülkede altın az olduğundan para- 
lar genellikle gümüştendir (Jenkinson, 1886, s. 85)4. Daha sonra Han'ın huzuruna çıkan Jenkinson, Korkunç Ivvan'ın mektubunu ona takdim etmiştir. Sarayın verdiği yemeğe katılan seyyah, görüşmeler esnasında Han'la birlikte, Han'ın kendisi ve Büyük Türk'ün (Kanuni Sultan Süleyman) gücü; ayrıca İngiltere ve Buhara'daki kanunlar ve dini hayat üzerine sohbet etmiştir. Bu esnada tüfeklerle de

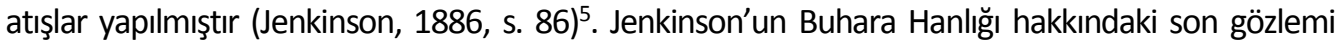
ticaret üzerinedir. Seyyaha göre Buhara şehrine Hindistan, İran, Belh, Rusya gibi ülkelerden ve bazen de Çin'den tacirler kervanlarla gelmektedir. Hintliler beyaz kumaşlar getirirler, ancak altın, gümüş, değerli taşlar ile baharatlardan hiç getirmezler. Buhara'dan ise işlenmiş ipek, kızıl deri, köle ve atlar götürürler. İranlılar Buhara'ya yün kumaş, keten, işlenmiş çeşitli ipekler ve at getirir, buradan kızıl deriyle birlikte diğer Rus mallarını ve farklı ülkelerden gelen köleleri alırlar. Ruslar ise Buhara'ya kızıl deri, koyun derisi, çeşitli yün kumaşlar, ahşap kaplar, yular ve eyer getirirken, pamuklu kumaştan yapılmış çeşitli malları, çeşitli ipek kumaşları ise götürmektedir (Jenkinson, 1886, s. 8790). Jenkinson, yaptığı gözlemler sonucunda, Orta Asya'da ticaret yolların güvensiz olduğu, bu durumun da doğal olarak ticarete olumsuz yönde tesir ettiği kanaatine varmıştır ${ }^{6}$.

Jenkinson'un Rusya, İran ve Türkistan'da yapmış olduğu geziler boyunca tutmuş olduğu raporlar ve notlar, yaklaşık üç asır sonra E. D. Morgan ve C. H. Coote tarafından bir araya getirilerek 1886 yılında New York'ta yayımlanmıştır?.

\section{17. Asırda Buhara Hanlığı'na Gelen Batılı Seyyahlar ve Seyahat Notları}

\section{1. İ. D. Hohlov:}

Jenkinson'un 16. asırda Buhara'ya yaptığı seyahatten uzun bir süre sonra, Rusya ve Buhara Hanlığı arasındaki ilişkiler 17. asrın ilk çeyreği itibari ile tekrar canlandı. Buhara'da Astrahanlılar hanedanın (1599-1747) iktidara yeni geldiği mezkûr asır başlarında tahta çıkan İmamkulu Han (1611-1641), en başta ülkenin ekonomik yönden kalkınması ve bozkııın güney ve batısındaki olaylar hakkında bilgi sahibi olabilmek amacıyla, Rusya ile ilişkileri geliştirmenin öneminin farkında idi.

\footnotetext{
${ }^{4}$ Seyyahın vermiş olduğu bilgilerden Buhara'nın yoksul bir ülke olduğu akıllara gelebilir, fakat bu dönemin Abdullah Han'ın siyasi hayatının ilk yılları olduğunu hatırlatmak gerekir. Nitekim Abdullah Han'ın Buhara Hanlığı'nı ihya ettiği 16. asrın son çeyreğinde ülke abat olmuş, hazine dolmuş ve altın paralar piyasada yerini almıştır.

${ }^{5}$ Bu zamanda Abdullah Han'ın elinde bulunan tüfeklerin aslında onun da eline yakın bir zamanda Burhan Sultan'ın ordusundan geçtiğine dikkat çekmemiz gerekir. Bu tüfekleri Orta Asya'ya getirenler ise Safevilere karşı Özbeklerle müttefik olmak isteyen Osmanlılardır.

${ }^{6}$ Fakat iç karışıklıklar devrinin bitmesinden sonra, Abdullah Han'ın otoriter yönetimi sayesinde ülkenin tamamında asayişin sağlandığını ve böylece yüzyılın sonlarına doğru ticarette bir ivme yakalanabildiğini söyleyebiliriz.

${ }^{7}$ Bkz. Jenkinson, A. (1886). Early Voyages and Travels to Russia and Persia (Vol. I). (Edited by . E. Delmar Morgan, C. H. Coote), New York.
} 
Bu düşünceyle hareket eden Han, iktidarının ikinci yılı olan 1613'te Nevruz adında bir elçiyi, ilişkileri tekrar başlatmak, ticari fırsatları gözlemek ve Romanov hanedanının henüz 18 yaşındaki yeni hükümdarı Mihail Fedoroviç'in (1613-1645) siyasi gücünü öğrenebilmek amacıyla Moskova'ya gönderdi. Fakat Buhara'nın elçilik heyeti Moskova'ya ulaşmadan, Volga Nehri yakınlarındaki Samara'da 14 aylık bir süre Ruslarca alıkonuldu. Rusların buradaki amacı, o sıralar savaş halinde olunan İran'dan dönmekte olan ve hanlıklar coğrafyasından geçmek durumunda bulunan Rus elçilik heyetinin can güvenliğini garanti altına almaktı. Rusya'nın Buhara'nın olumlu yaklaşımına karşılık böylesi bir tavır sergilemesi o zaman için daha acil meselelerin çözümlenmesi gerektiğinden anlaşılabilir bir durumdur. Diğer taraftan da Orta Asya, henüz o sıralarda Rusya'nın tam olarak ilgi alanında değildi.

1619 yılına gelindiğinde Buhara hükümeti Adembeg adlı bir başka elçiyi Moskova'ya göndermiştir. Rus hükümetinin Rus köleler üzerindeki hassasiyetinin farkında olan İmamkulu Han, bu faaliyette kalıı ilişkilerin varlığına karşılık olarak hanlık bünyesinde bulunan Rus kölelerin geri gönderileceğine dair bir teklif sunmuştur. Buhara'nın bu cezbedici adımlarına karşılık olarak Romanovlar, iyi bir şekilde misafir ettikleri Buhara elçisi ile beraber, İvan Hohlov'u Rus elçilik heyetinin başında Buhara'ya göndermiştir. Diplomatik durgunluğun olduğu on yıllardan sonra Hohlov'un görevi, gelecekteki Rus misyonları için bir model olabilirdi. Buhara'nın kölelerin serbest bırakılması için verdiği söz üzerine, elçilik amaçlarını belirledi. Temel olarak Rus imparatorluk askerleri ve soylulardan oluşan tutsakların serbest bırakılması için, Hohlov'un yeni Rus diplomatik teşrifat kurallarına uygun olarak hareket etmesi ve Çar'ın hediyelerini Han'a sunması gerekli idi. Ona verilen talimatlara göre öncelikle İmamkulu Han, yeni Rus politik koşulları (yani Rusya'da karışıklık döneminin sona erdiği) ve Rusya'nın Kafkaslar ve Bozkır halklarına karşı tekrar hâkimiyetini tazelediği hakkında bilgilendirilecekti. Buna ilaveten, çağın diğer bütün elçilik heyetlerinde olduğu gibi Hohlov'a da "nakaz" adı verilen, elçinin protokoldeki hal ve hareketinden genel davranış tarzına, yolculuk boyunca gideceği rotadan asıl özel amaçlarına (yani casusluk faaliyetlerine) kadar pek çok direktifin yer aldığı bir talimatname hazırlanmıştı (Sela, 2013, s. 74-75).

Moskova'dan yolcuğuna başlayan Hohlov, Astrahan'a uğradıktan sonra Hazar Denizi yoluyla Türkmen bozkırına ayak basmıştır. Hive kontrolündeki sahrada Türkmen akıncıların saldıııına uğrayan kafile, zorlu bir süreçten sonra çok miktarda malını Türkmenlere kaptırarak önce Arap Han'ın veliahdının yönettiği Ürgenç'e varmış, burada da bir miktar malı bırakarak Hive'ye ulaşmışır (Sbornik Knyazya Hilkova, 1879, s. 389-394). Hive'de bir süre Arap Han'ın misafiri olan Hohlov, Buhara'ya hareket için yola çıktığında 80 kişilik bir Hiveli birlik tarafından katledilmek için takip edilmiş, fakat Buhara Hanlığı topraklarına girdiğinde bu tehlike atlatılmıştır (Sbornik Knyazya Hilkova, 1879, s. 395-397).

Payitahta vardığında İmamkulu Han'ın çıkan isyanı bastırmak için Semerkand'da bulunmasından dolayı devlet erkânınca karşılanan Hohlov, iç meselelerin durulmamasından dolayı İmamkulu Han ile iki defa olmak üzere Semerkand'da mülakat etmiştir. Görüşmeler sırasında başlıca konu olan Rus esirlerin serbest bırakılması hususunda İmamkulu Han, kendi sarayında bulunan Rus esirlerin kendi istekleri doğrultusunda ücretleri ödenirse gidebileceğini, diğerlerinin tespitine ise 
ülkenin içinde bulunduğu durumun da etkisiyle vakit ayıramayacağını, fakat er ya da geç Çar'ın isteğini yerine getireceğini bildirmiştir (Sbornik Knyazya Hilkova, 1879, s. 398-402). Buhara'ya dönen Hohlov kendi ücretini karşılamış dokuz ve parasını ödediği iki kişi ile beraber sahiplerinin serbest bıraktığı Rus esiri kurtarmıştır (Sbornik Knyazya Hilkova, 1879, s. 405).

Rusya'ya güvenli bir şekilde dönebilmek için İmamkulu Han'dan yarlık alan Hohlov, Hive'de Arap Han'ın iktidardan düşmesine sebep olan hanedan içindeki mücadeleden ötürü Rusya'ya İran yolu üzerinden geçmeyi düşünmüş, fakat Hiveli prensler Abeş ve illbars'ın teminatına güvenerek sonradan Hive topraklarından geçmeye karar vermiştir. Fakat Hive topraklarında bulunduğu sürede, pek çok hediyeyi prenslere teslim ettikten sonra Rus topraklarına adım atabilmiştir (Sbornik Knyazya Hilkova, 1879, s. 406-420).

İvan Hohlov'un elçilik görevi boyunca hazırladığı raporlar, Buhara Hanlığı'nda devlet mekanizmasının işlevinden siyasi vaziyete, bozkır halklarının durumundan ülkenin o dönemki sınılarına kadar 17. asrın ilk yarısı adına bilgiler içermektedir. Devlet mekanizmasında muhtelif unvanlar taşıyan devlet adamlarının ele aldıkları görevler, teşrifat kuralları kısıtlı da olsa Hohlov'un satırlarında göze çarpmaktadır. Kendisine verilen talimatnamenin gereği olarak Buhara ülkesinin genel durumunu gözlemlediği raporları ise her ne kadar çok ayrıntılı bilgiler içermese de, dönem itibariyle bir yabancının bakış açısını yansıttığı için Buhara Hanlığı tarihi çalışmaları adına önem arz etmektedir. Elçinin raporlarında ülkenin önemli merkezleri, sınırları ve çevre ülkelerle ilişkilerine değinilmiştir. Verilen bilgilere göre İmamkulu'nun kardeşi Nadir'in yönettiği Belh de, başkent Buhara gibi kendi başına bir idari yapılanmaya sahiptir ve şehrin civarındaki toprakları yönetme hakkı bu merkezin hanına aittir. Ayrıca Buhara halkının İmamkulu Han’a nazaran küçük kardeşi daha çok sevdiğini söyleyen elçi, Buhara'nın yönettiği topraklardan Belh'e sürekli bir göç hadisesi yaşandığından da bahseder. Bu durum elbette İmamkulu Han'ın biraz da fazla otoriter tavrından kaynaklanmış olabilir. Diğer taraftan Han'ın kardeşi Nadir Han'ın yönettiği Belh ile Hint-Türk Devleti arasındaki ilişkilerin pek dostane olmadığı, Taşkent'e hâkim Kazak lideri Tursun Sultan ile devam eden mücadelede, İmamkulu Han ve kardeşi Nadir'in birlikte hareket ettikleri ve isyancılara karşı üstünlük kurdukları elçinin notları arasındadır (Sbornik Knyazya Hilkova, 1879, s. 420-422). Buhara ordusu hakkında da bilgi veren Hohlov, süvari birliklerine dayanan ordunun mevcudiyetinin 100000 civarında olduğunu ve sayıca Hive ordusundan fazlalığını vurgulamaktadır. Hive Hanlığı hakkında da bilgiler veren elçi, o zamanlar Türkistan’a büyük bir yıkım getiren Kalmuk istilasının ülkeye bıraktığı enkazı da gözlemlemiştir (Sbornik Knyazya Hilkova, 1879, s. 423-424).

Aslında Hohlov'un üstlendiği görevin Rusya açısından başarıya ulaştığı söylenemez. Başta Hive Hanlığı bürokratları olmak üzere bölge sakinleri elçilik heyetinin mallarına büyük oranda el koymuş, fakat elçi mallarını bonkör bir şekilde elinden çıkarırken, coğrafya hakkında yeterli bir bilgi edinememiştir. Hohlov'un elçilik görevinden arta kalan notları 1879'da P. G. Hilkov'un eserinde yayımlanmıştır. Knez Hilkov, Rus İmparatorluk arşivinde Buhara'ya dair materyaller arasında bulunan 
Selim Serkan ÜKTEN

Hohlov'un yazmasını, 1493-1743 yılları arası Rus tarihine dair tarihsel belgeleri ihtiva eden külliyatında yayımlamıştır ${ }^{8}$.

\subsection{O. Gribov:}

Hohlov başkanlığında Orta Asya'da gerçekleşen üzücü deneyim, Rus tarafını hayal kırıklığına uğratmış ve bundan ötürü çarlık Orta Asya'yı daha yakından tanımak için bölgeye daha fazla görevli göndermeye karar vermiştir. Çarlığın, Hohlov'dan yaklaşık 20 yıl sonra Hive ve Buhara'ya gönderdiği ikinci isim A. Gribov'dur. 1641 baharında önceki göreve paralel olarak, Rus köleleri kurtarmak, hanlıkların Osmanlı ve Gürcistan ile ilişkileri üzerine bilgi edinmek ve ticari fırsatları yakalamak için yola koyulan Gribov, esasen bir asker değil tacirdir ve daha önce de Orta Asya'da bulunmuş olup, Türk dillerini konuşabilmektedir.

Gribov seyahati boyunca, Hohlov'a nazaran daha büyük sıkıntılar ile karşı karşıya gelmiştir. Her şeyden önce Hive topraklarında Türkmenlerin muhalefeti üzerine çok yavaş hareket edebilmiş, bu sebepten Ürgenç'e beklenenden daha geç ulaşabilmiştir. Hive Hanlığı'nda yaşadığı zorluklardan sonra nihayet Buhara'ya varan elçinin maruz kaldığı muamele, şaşılacak şekilde Hive'dekinden farksızdır. Görevi boyunca hanlık makamına yeni oturmuş Nadir Muhammed Han'ın (1641-1651) soğuk tavırlarına maruz kalan elçinin kölelerin serbest bırakılması ile ilgili talebi reddedilmiştir. Buhara'da bulunduğu sürece daima casus muamelesi gören Gribov, Buhara devlet görevlileri kanaIıyla Han'a bir kez daha ulaşmaya çalışsa da, muvaffak olamamıştır. Daha sonra Karşi'ye hareket eden Han'ı takip ederek onun huzuruna çıkmayı başaran elçi, ikinci defa da kölelerin serbest bırakılması konusunda Han’ı ikna edememiştir. Gribov, Moskova'ya dönerken ikisi kadın biri erkek sadece üç esiri fidye karşılında kurtarabilmiştir.

Gribov Buhara'da bulunduğu sürede hanlıkta yaşanan önemli gelişmelere tanık olmuştur. Bu süre zarfında Buhara, Harezm'i topraklarına katmış ve Kazaklarla müttefik olarak Cungarlara karşı büyük bir savaş başlatmıştı. Seyahati boyunca bu siyasi gelişmeleri not eden elçi, çarlığı bunlardan haberdar etmek için 1643'te Moskova'ya dönmüştür (Sela, 2013, s. 79).

Çarlık, 1646'nın sonlarına doğru Gribov'u, Buhara'ya ikinci defa gönderme teşebbüsünde bulunmuştur. Çar Mihail Fedoroviç'in ölümünden sonra yerine geçen oğlu A. Mihayloviç'in (16451676) karar kıldığı bu elçilik görevinde amaçlananlar, ticari fırsatlar keşfetmek ve kölelerin serbest bırakılmasını sağlamanın yanı sıra, Hindistan'daki Babürlülerle ticari münasebetlere girmekti. Zira Hazar-Hive hattı artık güvensiz sayılıyordu. Bu misyonlarla İran üzerinden Buhara'ya yönelen elçi, Buhara'da baş gösteren iç isyanların etkisi ile Buhara'ya ilerlemeden İran'da kaldı (Sbornik Knyazya Hilkova, 1879, s. 451; Sela, 2013, s. 80; Barthold, 2004, s. 254). Gribov'un elçilik görevi boyunca

\footnotetext{
${ }^{8}$ Bkz. Sbornik Knyazya Hilkova (1879). S. Peterburg, s. 388-439.
} 
Türkistan hakkındaki izlenimleri ise maalesef tarihi kaynaklar arasında yerini almamıştır. Bu yüzden onun elçilik görevi boyunca başından geçen buradaki birkaç ayrıntıdan başka bilgiye ulaşamıyoruz.

\subsection{Pazuhin Kardeşler:}

Rusya, uzun bir süreden sonra ilişkileri tekrar yenilemek için Orta Asya'ya yeni bir elçilik heyeti göndermeye karar verdi. Çar A. Mihayloviç adına elçilik görevini bu kez Boris Pazuhin ve Semen/Semyon Pazuhin adlı iki üvey kardeş üstlendi. Daha önceki elçilik hareketlerine nazaran daha geniş bir coğrafyada, daha geniş yetkilerle gerçekleşen bu elçilik görevi, doğal olarak 17. asırda Rusların Batı Türkistan'a gerçekleştirdiği görevler içerisinde en kapsamlı bilgileri vermesi açısından da bir adım öne çıkmaktadır (Sela, 2013, s. 80).

Pazuhinler esasen önceki Rus görevlerini devam ettirmek üzere Buhara'ya gönderilmişlerdir. Daha öncesinde olduğu gibi, çarın direktiflerinin bulunduğu bir talimatname verilen elçilerin başlıca yerine getireceği görevler arasında, Rus esirleri kurtarmak yine asıl konu olmuştur. Bunun yanı sıra Moskova-Astrahan hattından Hindistan'a yapılacak ticari faaliyetlerde Türkistan toprakları boyunca muhtelif ticaret yollarının keşfi, bu yolların güvenli olup olmadığı, mesafeleri ve Astrahan-Moskova hattı boyunca çarlığa daha fazla ipek satılması için Buharalı tacirlerin ikna edilmesi meselesi, Pazuhinlerin yerine getirmesi gereken diğer görevler arasındadır. Elçilik heyetine ayrıca geleneğe uygun olarak Buhara, Belh ve Ürgenç'te bulundukları sürede hanlıklara dair gözlemledikleri ayrıntıları gizlice not etme direktifi de verilmiştir (Nakaz Borisu i Semenu Pazuhinım, 1894, s. 11-14).

Bu görevleri yerine getirmekle yükümlü olan Pazuhinler, 1670'te öncelikle Hive'ye varmışlardır. Bu tarihlerde Hive tahtında bulunan Anuşa Han tarafından nezaketle karşılanan Pazuhinler, Çar'ın mektubunu Han'a iletmişlerdir. Anuşa Han, özetle Rus esirlerin serbest bırakılması meselesini içeren mektuba karşılık kendisinde hiç Rus esir olmadığını, Hive, Ürgenç ve diğer şehirlerde bulunan esirlerin ise Kalmuk, Başkurt gibi halklardan parayla satın alındıklarını söyleyerek, bunların sadece fidye karşılığında bırakılacağını bildirmiştir. Taraflar paranın ödenme usulü konusunda bir mutabakata varamayınca, Boris Pazuhin durumu Çar'a ileteceğini söyleyerek Buhara'ya gitmek için müsaade istemiştir (Nakaz Borisu i Semenu Pazuhinım, 1894, s. 39-43).

Hive hanına samur kürkü ve kumaş gibi çeşitli hediyeler sunarak Buhara yoluna koyulan Pazuhinler, Haziran 1670'te Buhara Hanlığı topraklarına vardığında, Buhara hanı Abdülaziz Han (16511681) merkeze isyan halinde olan hanlığın ikinci merkezi durumundaki Belh'e yönelmiş durumdadır. Han'ın Buhara'da olmadığı sürede şehre yakın bir noktada yaklaşık altı ay konaklayan Pazuhinler, nihayet Aralık ayında Buhara'ya dönen hanın huzuruna çıkmışır. Teşrifat kurallarının ayrıntılı bir şekilde aktarıldığı birkaç kabul gününde dostluk, ticaret, esirler ve özgür durumdakiler hakkında konuşulmuş, lakin Abdülaziz Han, Çar'ın mektubuna karşılık elçilik heyetine cevabı hemen vermemiştir. Nihayet uzun bir sürenin ardından elçilerin ısrarcı tutumları netice vermiş ve ilk etapta Abdülaziz Han'ın dokuz esiri, heyete teslim edilmiştir. Daha fazla esirin serbest bırakılması için ise düzenli aralılarla elçilik heyeti gönderilmesi Buhara hükümetince heyete bildirilmiştir (Nakaz Borisu i Semenu Pazuhinım, 1894, s. 43-56). Han'dan gönderilecek mektubu alana kadar ülkedeki Rus esirlerin durumunu gözleyen Pazuhinler, bunların hanlıklarca daha ziyade Kalmuklar ve Başkurtlardan 
satın alındığını tespit etmişlerdir. Gizlice görüştükleri Rus esirlere, özgürlükleri için çabalamalarını tavsiye ederlerken, onların maruzatını içeren mektuplarını da Çar’a iletmek üzere teslim almışlardır. Pazuhin kardeşler Hive, Buhara ve Belh'te bulundukları sürede yolculuk masrafı ve hanlara verdikleri hediyeler dışında kalan para ile Rus esirleri hanlık topraklarının muhtelif noktalarından satın alamaya çabalamışlardır. Fakat elçiler, köleler üzerinde birçok hakka sahip olan esir sahiplerinin, bunları satmamak gibi bir hakka da sahip olmalarından ve kölelerin pahalılı̆̆ndan ötürü istenilen ölçüde kölenin özgürlüğünü kazanmasına vesile olamamışlardır (Nakaz Borisu i Semenu Pazuhinım, 1894, s. 57-59). Elçilik heyeti, bu gibi sebeplerden dolayı Rusya'ya beraberlerinde yirmiden biraz fazla köle ile dönebilmişlerdir.

Bir süre sonra Pazuhinlere, Abdulaziz Han'ın onları huzuruna davet ettiği haberi gelmiştir. Elçiler için verilen yemekten sonra Han, Buhara ve Rusya arasındaki ticaretin geliştirilmesi gerektiğini temenni etmiş, özgürlüğünü kazanan kölelerin alıkonulamayacağını ve elçilerin gelip gittikçe daha fazla kölenin serbest kalacağını heyete bildirmiştir. Elçilik heyetinin ise Çar'ın mektubuna karşlık bir mektup alma talepleri netice vermiş ve Han'ın, Çar'a verdiği cevapları içeren mektup Pazuhinlere teslim edilmiştir. Pazuhinler nihayet 17 Kasım 1671'de İran yolu üzerinden Buhara'dan ayrılmışlardır (Nakaz Borisu i Semenu Pazuhinım, 1894, s. 65-67).

Pazuhinlerin elçilik notları yabancı bir gözlemcinin Buhara Hanlığı hakkında vermiş olduğu ilk kapsamlı bilgileri içermesi bakımından muazzam bir kaynak niteliği taşımaktadır. Elçilik notlarının bütününe bakıldığında, Pazuhinler, Buhara topraklarına girdikleri andan itibaren iştirak edilen toplantılardaki teşrifat kurallarını, sarayda bulunan devlet görevlilerini ve onların ele aldıkları görevleri incelemişlerdir. Bunun yanı sıra onların raporlarında Çar'ın vermiş olduğu talimatnameye göre Buhara Hanlığı'nın diğer hanlıklar ve devletlerle olan siyasi ilişkileri, askeriyesi ve bölge ticaret yollarının durumu hakkındaki bilgilerin detaylı olduğu göze çarpmaktadır.

Özellikle Han'ın elçileri kabulünün tasvir edildiği kısımda, bazı devlet görevlilerinin teşrifattaki yeri ve ele aldıkları görevler, Buhara'nın yerli vakayinameleri dışında karşılaştığımız ilk değerli bilgiler olması bakımından önemlidir. Bu kısımda devlet görevlileri arasında önemli bir mevkide olan divanbegi ${ }^{9}$ (atalık unvanından sonra gelmektedir), elçiler ile han arasındaki iletişimi sağlamaktan sorumlu olmuştur (Nakaz Borisu i Semenu Pazuhinım, 1894, s. 49). Bunun yanı sıra dini görevliler, emirler ve diğer saray görevlilerinin, teşrifat ya da yemek merasimlerinde hangi mevkilerde yer tuttukları ve tahta göre konumları ayrıntısı ile belirtilmiştir. Yemek merasimi sırasında oturma düzeni, yemeğin sunuluş biçimi (ki yemekler öncelikle hiyerarşide yüksek mevkide bulunan görevlere verilir), yemek türleri ve diğer adetler hakkında ayrıntılar bulunmaktadır. Han'ın Pazuhinlere verdiği

\footnotetext{
${ }^{9}$ Timurlular devrinden itibaren Türkistan'da görmeye başladığımız divanbegi unvanının sahipleri, esasen mali ve finansal durumdan, vergi tahsilinden ve devletin dış siyasetinden sorumluydular. Ayrıca askeri aristokrasi geleneğinin bir sonucu olarak, bir birliğin başında seferlere de iştirak ederlerdi. Tafsilatlı bilgi için bkz. (Ükten, 2015, s. 84-85).
} 
bir yemekte sofrada emir ve komutanlar aynı yükseltide oturmuşlardır. Tahtın sağ tarafındaki yükseltide hocalar ve din adamları oturmaktadır. Hanın önünde kılıcı, sadağı, çelik kalkanı bulunmaktadır. Han'ın tahtının arkasında ise on iki kişi bulunmaktadır. Ellerinde asa ve kıııcları vardır ve sürekli yer değiştirmektedirler. Ayrıca Han’ın önünde asaları ile yasavullar ${ }^{10}$ (200 kişi) durmaktadır. Onların arkasında iki taraftaki yükseltide dokuzar kişi ellerinde tüfeklerle durmaktadır. Sofradan sorumlu kişi mihterdir. O yemeklerin tadına baktıktan sonra yemekler hanın önüne konulmaktadır. Hanın önünde ihtişamı göstermek için altından ve çiniyle süslenmiş kâseler, piyaleler ve tabaklar bulunmaktadır. Yemek yenildiği sırada dokuz kişi dans etmekte ve şarkılar söylemektedir (Nakaz Borisui Semenu Pazuhinım, 1894, s. 52-53).

Dış siyasette Buhara Hanlığı'nın Osmanlı Devleti ile dost ya da düşman herhangi bir iletişiminin olmadığı, diğer taraftan İran ve Babürlerle ilişkilerin o dönem için dostça olduğu rapor edilmiştir. Uzun bir süre çatışma halinde olunan Hive Hanlığı ile ilişkilerin de iyi olduğu vurgulanır, hatta Abdülaziz'in Belh hâkimi kardeşi Sübhankulu (1681-1702 yılları arasında Buhara tahtında) ile olan ihtilafında Hive hanı Anuşa'dan askeri yardım aldığı elçiliğin notlarında mevcuttur. Rusların elçilik faaliyetlerinde en çok üzerinde durduğu konulardan biri kuşkusuz rakip devletin askeri durumu hakkında bilgi edinebilme olduğundan, Pazuhinlerin bu noktada vermiş olduğu bilgilerde titiz bir gözlemde bulundukları söylenebilir. O dönemde Buhara'nın toplamda 150000, Belh'in ise bunun yarısı kadar askeri bulunduğunu aktaran elçiler, hanlığa bağlı Kazak ve Karakalpak halklarından elde edilen yardımcı birliklerin, hanlığın kendi askeri sınıfından (nökerler) daha etkili ve sadık olduklarını vurgularlar. Tamamı süvari olan ordunun o çağa göre ateşli silahlar konusunda geride olduğuna dikkat çekilir. Zira ülkede kundaklı veya tekerlekli top yoktur. Sadece develer üzerinde taşınabilen zenburek adı verilen küçük kalibreli toplar vardır. Pazuhinler bu kısımda Hive ordusu hakkında da bilgi vermiştir. Adı geçen hanlığın da askeri güç olarak Buhara Hanlığı'ndan farklı bir tarafı neredeyse yoktur (Nakaz Borisu i Semenu Pazuhinım, 1894, s. 60-61).

Elçilerin gözlemde bulundukları bir başka mevzu da Hindistan'a giden ticaret yollarıdır. Onların hesaplamalarına göre Astrahan'dan Hint hükümdarının başkenti Canabad'a en uygun yoldan bir kervanın gidişi deve yürüyüşü ile dört ay iki haftadır. Çarlığın, elçilerin Orta Asya'da bulundukları sürede gözlem yapmalarını istediği bölgelerden biri de Belh olduğundan, Boris Pazuhin bölgeye tercümanlarından M. Medvedev'i gizli bir şekilde göndererek bilgi toplamasını istemiştir. Çarlığın bölge ile alakalı öğrenmek istediği üç ana mevzu, Sübhankulu Han ile dostluk kurulup kurulamayacağı, Hindistan ticaret yolunun tespiti ve Rus esirlerin durumu idi. Boris Pazuhin kendisine gelen raporda Belh sultanı Sübhankulu'nun Çar ile dostluk kurmak istediği, Belh sarayında 100 civarında

\footnotetext{
${ }^{10}$ Çingiz Han döneminden itibaren Türk-Moğol devletlerinde rastladığımız bu rütbenin sahipleri, han yasalarına göre şekillenmiş emirleri yerine getirmekle mükellefti. Buhara Hanlığı’nda düşük derecedeki saray görevlileri arasında yer alırlarken, özellikle seferler sırasında ön plana çıkarak, han, emir ve komutanlar tarafından buyrulan emirleri yerine getirilerdi. Buhara Hanlığı'nda yasavullar, asker toplama, orduyu düzene sokma, ganimeti bir yere toplama ve elçilik görevi gibi birbirinden farklı görevleri üstlenebilirlerdi. Tafsilatlı bilgi için bkz. (Ükten, 2015, s. 107-108)
} 
Selim Serkan ÜKTEN

fiyatları pahalı Rus esir bulunduğu ve Belh'ten Hindistan'a giden ticaret yollarının güvenli olup, buradan vergi alınmadığı haberini almıştır. Diğer taraftan Belh ve Buhara arasındaki siyasi ilişkileri de gözlemleyen elçi, dönem itibariyle hanlığın merkezi Buhara ve ikinci merkezi Belh arasındaki husumete değinmiştir. Uzun süren savaşlar yüzünden iki şehri birbirine bağlayan yollar güvensiz, ölüm riski de oldukça fazladır (Nakaz Borisu i Semenu Pazuhinım, 1894, s. 62-63).

Pazuhinlerin elçilik notlarının bütününü içeren nüsha, Rusya'da Arkeografi Komisyonu tarafından 1872-1927 yılları arasında yayımlanan, tarihi belgeleri ve edebi eserleri içeren külliyat serisi içerinde yer almaktadır ${ }^{11}$.

\section{18. Asırda Buhara Hanlığı'na Gelen Batılı Seyyahlar ve Seyahat Notları}

\subsection{F. Beneveni:}

17. asrın son çeyreğinde Büyük Petro'nun (1689-1725) Rus tahtına çıkmasıyla birlikte Uzak Doğu ve İslam dünyasıyla ilişkilerde yeni bir dönem başlamıştır. 17. asırdan miras kalan ticari sorunlar, onun döneminde daha derli toplu bir şekilde masaya yatııımıştı. Rusya'yı dünyaya açma idealiyle yola çıkan Çar, zamanında Hazar Denizi'ne döküldüğünü öğrendiği Amu Derya'nın eski yatağını keşfetmek ve nehir yoluyla Hazar-Hindistan ticaret yolunu tekrar kurmak amacıyla Kafkas asıllı Aleksandre Bekoviç Çerkeski'yi 4000 civarında düzenli bir ordu ile bölgeye göndermişti. Çar'ı bölge için heyecanlandıran tek mevzu nehir ticaret yolu değil, eski nehir yatağında bulunduğu rivayet edilen altın kaynaklarıydı. Çerkeski'nin 1714'te Doğu Hazar kıyılarındaki faaliyetleri hızı başlamış, fakat Hive Hanlığı'nın çarlığın asıl maksadını öğrenmesi ve Çerkeski'yi 1717'de bertaraf etmesiyle bu keşif faaliyeti başarısızlıkla sonuçlanmıştı (Barthold, 2004, s. 285-289).

Bu başarısız girişimden sonra, Çar Petro'nun Hazar ötesini keşfetme düşüncesi fazlasıyla devam etmiş ve bu kez Hive ile birlikte Buhara Hanlı̆̆ı'nda da olup bitenlerin öğrenilebilmesi amacıyla İtalyan asıllı Florio Beneveni'nin başında bulunduğu bir elçilik heyeti görevlendirilmiştir. Önceki görevlerde olduğu gibi hanlık coğrafyasının genel yapısı, önemli kaleleri, ülkenin rakip devletlerle olan ilişkileri, ticari faaliyetleri ve bölgenin madenleri hakkında olabildiği kadar istihbarat toplaması emredilen (Bkz. Beneveni, 1986, s. 1-7) Beneveni ve beraberindeki heyet, Kafkasya ve İran'dan geçerek 1721 yılında Buhara'ya ulaşmıştır. Bu dönemde Buhara Hanlığı'nda Astrahanlılar Hanedanı’nın son hükümdarı Ebulfeyz Han (1711-1747) tahtta oturmaktadır. Genel atmosfere bakıldığında ise, han ile Özbek kabileleri arasında yaşanan kıyasıya rekabet ve bunun neticesinde ortaya çıkan kargaşa döneme damgasını vurmakta, hanlık topraklarının büyük kısmı da bu kaos ortamında yerel

\footnotetext{
${ }^{11}$ Bkz. Nakaz Borisu i Semenu Pazuhinım, Poslannım v Buharu, Belh i Yurgenç 1669 (1894), (Red.: A. N. Truvorova), Ruskaya istoriçeskaya Biblioteka, 15, S. Peterburg: Arheografiçeskoy Kommissii, ss. 1-91.
} 
yöneticiler olan kabile reisleri tarafından bağımsız olarak yönetilmektedir ${ }^{12}$. Beneveni'nin birkaç yıl bulunmak zorunda kaldığı bu karışık ve güvensiz ortamda, hanlığın genel durumu, komşuları ile olan ilişkileri ve hanlığın doğal kaynakları üzerine hazırladığı raporlar, kaynak olarak döneme ışık tutacak değerli bilgileri intiva etmektedir.

Beneveni'nin Buhara Hanlığı'nda bulunduğu süre zarfında yapmış olduğu gözlemleri, hanlığın, özellikle de başkent Buhara'nın yaşanan iç mücadelelerde bir hayli yıprandığını gözler önüne sermektedir. Muhtelif Özbek kabileleri merkeze savaş açmış, Han’a bağılığını bildiren kabile reisleri dahi Han için savaşmak yerine yeri geldiğinde isyancılara katılmaktadır. Bu durumda ordunun ana iskeletini oluşturan kabile askerleri nökerler yerine Han'ın yanında neredeyse sadece hassa ordusuna mensup köle kökenli Kalmuk ve Rus muhafızlar bulunmaktadır ve Han, şartlardan ötürü saray dışarısına pek de çıkamamaktadır (Beneveni, 1986, s. 69). Diğer taraftan Buhara'yı tedirgin eden bir diğer mevzu da bazı Özbek kabilelerinin Ebulfeyz Han’a karşı Çingiz neslinden Recep Han'ı destekleyerek, Buhara'yı ele geçirmesi için onun yanında yer almalarıdır. Özbekler sayesinde Semerkand'da tahta oturan Recep Han'ın Buhara'ya askeri harekâtta bulunacağı korkusu hanlıkta büyük bir korkuya ve kargaşaya sebep olmaktadır. Buhara'da hal böyle iken Beneveni'nin casus olduğuna dair söylentiler Ebulfeyz Han'ın kulağına gittiğinde, elçi, harem ağasının Han'ı ikna etmesi sayesinde ölümden kurtularak 1725'te 27 kişilik bir grupla Buhara'dan ayrılarak Hive'ye varmıştır (Beneveni, 1986, s. 78-98).

Beneveni, Buhara'da bulunduğu uzun süre zarfında Çar Petro tarafından kendisine tebliğ edilen yedi ana maddeden oluşan talimatnamede istenilenleri ayrıntısı ile rapor etmiştir. Bölge coğrafyasını detaylı bir şekilde inceleyen elçi, her bir hanlığın kaçar yerleşim birimine sahip olduğunu, şehirler arasındaki mesafeyi ve Amu Derya Nehri'nin akış güzergâhını tespit edebilmiştir. Bu notlar hanlık coğrafyasında Rusça bilindiğinden güvenlik gereği İtalyanca alınmıştır (Beneveni, 1986, s. 119). Çarın verdiği talimatname gereğince kabul sırasındaki seremoni kuralları da incelenmiştir. Elçinin talebi doğrultusunda sadece kendisi at üzerinde saraya girebilirken, beraberindekiler yaya

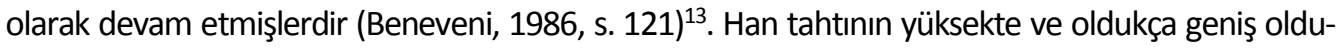
ğunu vurgulayan elçi, basamaklar boyunca devlet görevlilerinin hiyerarşiye uygun olarak yer tuttuklarını ve kendisinin İran elçisine göre daha iyi bir yere oturtulduğunu raporuna yazmıştır (Beneveni, 1986, s. 122). Beneveni'nin ordu hakkında verdiği bilgilere bakılırsa, Buhara Hanlığı askeri açıdan çok geri kalmıştır. Devlet ateşli silah teknolojisinde çok geridedir ve elde bulunan top ve tüfekler neredeyse hiç işe yarar durumda değildir. Ülkede halen Abdullah Han zamanından kalma

\footnotetext{
12 Ebulfeyz Han döneminde yaşanan iç mücadeleler ve bunun sebepleri için bkz. (Ükten, 2017, s. 82-85; Alpargu, 2002, s. 567).

${ }^{13}$ Buhara sarayına at üzerinde girip girememek, kişinin devletteki veya toplumdaki konumunu gösteren önemli detaylardan biridir. Bu detaya 18. asrın son çeyreğinde kaleme alınan Mecmuu'l-Erkam adlı kronikte de dikkat çekilmiştir bkz. (Mirza Badi Divan, 1981, s. 97-98).
} 
toplar bulunmakta olup, bunlar bir köşede yatmaktadır. Topları kullanmayı bilen ustalar da yoktur. Sadece Rus esirler top kullanmaya zorlanmaktadır. Han'ın güvenliğini ise sayıları bini geçmeyen, Rus ve Kalmuk kölelerden devşirilmiş muhafızlar sağlamaktadır. Zira Özbek kabilelerinin askerlerine devletin içinde bulunduğu iç savaş yüzünden güvenilmemektedir. Elçi, ülkenin içerisinde bulunduğu karışık durumdan ötürü yerel bölge hâkimlerinin, bölgelerini merkezden bağımsız yönettiklerini ve o dönem için hanlığa ait 23 şehir bulunduğunu bildirir (Beneveni, 1986, s. 123-125).

Beneveni’nin raporlarında, o dönem için hanlığın içerisinde bulunduğu durum iyi özetlenir. Özbek kabilelerinin merkezden ayrılmasından ötürü derli toplu bir orduya sahip olamayan Han'ın hazinesi de boştur. Bu yüzden rakip devletler dışında, bağımsızlıkçı Özbeklerden de çekinilmektedir. Hive hanı Şirgazi'nin Buhara şehrine çok yakın mevkilerde gerçekleşen yağma akınları söz konusudur. Öyle ki bu karmaşık durumda Buhara halkı çevre ülkelere göç etmek zorunda kalmaktadır. Elçinin bildirdiğine göre bu süreçte 400000 insan Buhara Hanlığı'ndan Hint-Türk Devleti'ne göç etmiştir. Geri kalan halk ise o kadar bezmiştir ki, Özbek yönetimi altında olmaktansa Kalmuk yahut Rus iktidarına razıdırlar (Beneveni, 1986, s. 126-129). Elbette ki böylesi bir süreci yaşayan devlette ticaret de durma noktasına gelmiştir. Hâlbuki ülkedeki ticari potansiyeli görebilen elçi, ticaretin tekrar canlanmasının, Özbek topraklarında birliğin sağlanmasına ve Kazak, Türkmen gibi toplulukların yağmalarının sona ermesine bağlı olduğunu vurgulamaktadır. Elçi sadece Kazak veya Türkmenlerin değil, bazen Özbeklerin de Rus veya Müslüman olsun önüne geleni yağmalamayı düşündüklerinden bahsetmektedir. Ayrıca sönme noktasına gelen ticarette, buraya gelen bir tüccarın malını hemen satması da kolay değildir. Zira alım gücü zayıftır. Alınsa da veresiye alınır. Tacirin biri diğerinden mal alıp üç yıl sonra vermek istese, bu Özbek kanununa göre mümkündür. Beneveni, eğer bu topraklar ele geçirilemezse uygun ticari güzergâhlardan yapılacak ticaretin kaç gün sürebileceğini hesaplamış, ortaya çıkan süreden de bunun güçlüğünü gözler önüne sermiştir (Beneveni, 1986, s. 71,129-130). Talimatlara göre Buhara Hanlığı'ndaki yer altı kaynaklarını da araştıran Beneveni, ülkenin altın ve gümüş madenlerinin nerede bulunduğunu tespit etmiştir (Beneveni, 1986, s. 65). Fakat elçi Orta Asya'nın zenginliklerini biraz abartmıştır (Barthold, 2004, s. 290).

Beneveni gözlemleri doğrultusunda Hive, Buhara ve Kazak Hanlıklarını ele geçirebilmek için çok az sayıda düzenli bir ordunun yeterli olacağını düşünmektedir. Kazak Hanlığı'nı işgal etmek için Kalmuklarla ittifak yapabilmek, Özbek ve Türkmen bölgelerinin işgali için ise onların düşmanı olan Karakalpaklardan yararlanabilmek mümkündür (Beneveni, 1986, s. 131-133). Beneveni'nin Buhara Hanlığı topraklarında bulunduğu süre zarfında tutmuş olduğu raporların bütünü bir araya getirilerek 1986 yılında Moskova'da yayımlanmıştır ${ }^{14}$.

\footnotetext{
${ }^{14}$ Bkz. F. Beneveni. (1986). Poslannik Petra I. na Vostoke Posol'stvo Florio Beneveni v Persiyu i Buharu v 1718-1725 godah, Moskva: Glavnaya Redakstiya Vostoçnoy Literaturı İzdatel’stva “Nauka”.
} 


\subsection{N. Grigoryev:}

Erken Mangıtlar döneminin en önemli tanıklarından biri olarak karşımıza çıkan Grigoryev, aslen Osmanlı ülkesinden bir Rum'dur. Seyyahın Buhara'da bir tanık olarak bulunmasının sebebi ise bir görevden ötürü değil, tacir olarak geldiği ülkede bazı sebeplerden dolayı rehin kalmasıdır. Buhara'da bulunduğu sürede yaptığı gözlemler ise Mangıtların ilk dönemi hakkında verdiği detaylardan ötürü büyük bir önem arz etmektedir. Seyyahın Buhara ülkesi hakkındaki notları aslında 1752 yılında Rusya'ya varmasından sonra düzenlenmiştir. Yaklaşık 18 yıl Buhara'da rehin olarak kalan ve daima Buhara'dan kurtulmanın yollarını arayan Grigoryev, bir yolunu bularak ülkeden ayrılmıştır. 1752 yılında geldiği Orenburg eyalet idaresinde ise başından geçen olayları anlatmış ve böylece onun Buhara ülkesi hakkındaki gözlemleri kaynaklar arasındaki yerini almıştır (İstoriçeskie İzvestiya o Kirgiz-Kaysakah, 1853, s. 8).

Ruslara verdiği ifadeye göre 19 yı önce yani 1733'te ticaret yapma amacıyla vatanından ayrılan tacir, sırasıyla Astrahan, Meşhed gibi şehirlerde ticaret yaptıktan sonra Buhara'ya geçmiştir. Burada bulunduğu süreçte mallarını nakit paraya satamadığı için veresiye vermiş ve alacaklarını temin etmek için uzun bir süre Buhara'da yaşamak zorunda kalmıştır. Ancak bu süre zarfında tacir giderek zenginleşmiş, hatta soylu ve zenginlerden alacaklarına karşılık birkaç köy dahi elde edebilmiştir. Başta Mangıt hanedanının kurucusu atalık Muhammed Rahim Biy (1747-1759) olmak üzere Buharalıların saygınlığını kazandıktan sonra, işlerini büyüterek Buhara ipek ve kumaşını İran'ın Meşhed ve İsfahan şehirlerine, Badahşan'a, Hindistan'a ve Taşkent'e pazarlamaya başlamıştır. Ancak yönetim tarafından ülkeden ayrılmasına izin verilmemiştir. Her ne kadar zenginlik içerisinde olsa da artık Buhara'da yaşayamayacağına karar veren tacir, Atalık Muhammed Rahim Biy'in onayıyla Rusya'da ticaret yapma bahanesini ileri sürerek ülkeyi terk etmiş ve buraya bir daha dönmemiştir. (İstoriçeskie İzvestiya o Kirgiz-Kaysakah, 1853, s. 9-12).

Grigoryev, Buhara Hanlığı ve Türkistan coğrafyasını Rus görevliler gibi çok ince detaylarına kadar gözlemlememiş olsa da, onun hatıraları Muhammed Rahim Biy dönemi hakkında bilgiler veren ender kayıtlardan biri olması sebebiyle oldukça kıymetlidir. Buhara şehrinin genel yapısı hakkında bilgi veren seyyah, şehrin etrafını çevreleyen 2,5 sajen ${ }^{15}$ genişliğinde, 3,5 sajen boyunda çamurdan surlardan bahsetmektedir. Bu surların çoğu yerde bakımsızıktan çöktüğünü ve istilalara karşı yeniden ıslah edildiğini vurgulamaktadır. Şehrin yakınlarındaki nehirlerden elde edilen suyun tarımsal faaliyetler için önemine değinilmektedir. Fakat şehrin su ihtiyacını karşılayan nehrin düşman kuşatması sonucunda tutulması durumu, şehir için felaketin habercisidir. Diğer ziyaretçilerin de vurguladığı üzere Buhara'daki temiz su sıkıntısından bahseden Grigoryev, içme suyundaki kirlilikten ötürü meydana gelen rişta hastalığına değinmiştir. Zira Buhara'da bulunduğu süre zarfında bu hastalıktan muzdarip olanlardan biri de bizzat kendisidir (İstoriçeskie İzvestiya o Kirgiz-Kaysakah, 1853 , s. 13-14).

${ }^{15}$ Eski bir Rus ölçü birimidir. 1 sajen 2.13 metreye denk gelmektedir. 
Grigoryev notlarında Buhara'nın yakın tarihine değinmiştir. Atalık Muhammed Rahim Biy'in bir darbe ile Ebulfeyz Han'ın hâkimiyetine son vererek, iktidara nasıl geldiği kısaca anlatılır. Iktidarın ele geçirilişinde Rahim Biy'in İran'dan beraberinde getirdiği 500 civarında Afgan'ın kendisine sağladığı katkıya değinilir (İstoriçeskie İzvestiya o Kirgiz-Kaysakah, 1853, s. 16).

Grigoryev dönem itibariyle tarımsal faaliyetlerin iyi durumda olduğunu, ancak otlak eksikliğinden ötürü yem için sürekli hasat yapıldığından bahsetmektedir. Bol miktarda sebze ve meyvenin yanı sıra, ülkede ipek üretimi de yapılabilmektedir. Kendisinden sonra bölgeye gelen seyyahlardan farklı olarak, Buharalıların altını dışarıdan değil nehir yataklarından elde ettiklerinden bahsetmektedir. Bununla birlikte Buharalıların, ülkede önemli altın madenleri olmasına rağmen, gerekli donanımlarının olmamasından dolayı bunları çıkaramadıkları seyyah tarafından vurgulanmaktadır. Ülkede gümüş ve bakır da Nadir Şah hayatta iken onun ülkesi İran'dan temin edilmiştir (İstoriçeskie İzvestiya o Kirgiz-Kaysakah, 1853, s. 17-21).

Grigoryev'in verdiği en dikkate değer bilgilerden biri de askeriye hakkındadır. Mangıt hanedanının kurucusu Muhammed Rahim Biy'in, Afşar Devleti'nden aldığı askeri miras hakkındaki detaylar seyyahın gözlemleri arasında olmuştur. Grigoryev'in verdiği detaylara göre Muhammed Rahim Biy, Buhara'da çok uzun bir aradan sonra top dökümünü gerçekleştirebilmiş bir hükümdar olmuştur. Bu dönemde Buhara'da bakır ve demir, hatta demirin yetersizliğinden ötürü tabak ve çanakların eritilmesiyle dökme demir toplar yapılabilmiştir. Yine demirden tüfekleri Buharalılar kendileri imal etmişlerdir. Tüfek ve barutta Buharalıların hocalığını ise zamanında Nadir Şah'ın hizmetinde bulunan ve onun ölümünden sonra Buhara'ya yerleşen ustalar yapmışlardır (İstoriçeskie İzvestiya o Kirgiz-Kaysakah, 1853, s. 21).

Grigoryev'in notlarında Astrahanlılar hanedanının son dönemleri ile Mangıtlar iktidarının ilk dönemlerinde hâkim olunan bölgelerin karşılaştııılığı görülür. Ebulfeyz Han döneminde hâkim olunan şehirlerin zamanla hanlıktan koptukları veya bazı merkezlerin adem-i merkeziyetçi yapıyı desteklediklerine vurgu yapılır. Neticede Han'ın son dönemlerine gelindiğinde ise sınırlar giderek küçülmüş ve Mangttlara Miyankal, Şehr-i Sebz, Karşi, Gijduvan ve Karakul gibi önemli şehirlerin bulunduğu küçük bir ülke miras kalmıştır (İstoriçeskie İzvestiya o Kirgiz-Kaysakah, 1853, s. 22).

Seyyah son olarak Buhara Emirliği'nin ticaretine değinmiştir. İran ve Hindistan'la yapılan ticarette bu ülkelerden ipek ve ipekten yapılan kumaşlar alınmakta, hanlığın elinden çıkmış Taşkent'ten ise deri ve pamuklu kumaşlar ile koyun satın alınmaktadır. Burada verilen bir detay Buhara'da ticaretin her ne kadar kötü durumda olmasa da, bazı tehlikeleri olduğunu gözler önüne serer. Zira ticaret yolları eşkıyalar tarafından sarılmış olup, bunlar yirmişer kırkar ve yüzer kişilik gruplarla kervanları yağmalamaktadır. Orta Asya'daki düşüşün başlamasıyla giderek yaygınlaşan bu asayiş sorunu, yazarın ifadesine göre tacirlerin elinde bulunan tüfeklerle bertaraf edilebilmektedir. Bu yüzden yağmacılar nadiren muvaffak olabilmektedir (İstoriçeskie İzvestiya o Kirgiz-Kaysakah, 1853, s. 23-24). Fakat günümüzde yapılan pek çok araştırmadan da anlaşılacağı üzere, Orta Asya ticaretine en büyük darbeyi bu asayiş sorunu vurmaktadır. 
Grigoryev'in Buhara Emirliği'ne dair vermiş olduğu bilgiler, Kazaklara dair tarihsel bilgiler içeren ve 1853 'te Ufa'da yayımlanan eserde Velyaminov-Zernov tarafından derlenerek bilime kazandırımıştır ${ }^{16}$.

\subsection{F. Efremov:}

18. asırda Buhara Hanlığı'nda bulunmuş Rus seyyahlar içerisinde yer alan Filip Efremov'un hikâyesi de Grigoryev'inki gibi farklılık arz etmektedir. O çarlık tarafından özel bir görev için bölgeye gönderilmiş bir elçi ya da casus değildir. 1763 yllında Rus ordusunda göreve başlayan Efremov, ünlü Pugaçov isyanı ${ }^{17}$ sırasında Orenburg hattı civarında esir alınmış, daha sonra Kazaklara esir düşmüş ve onlar tarafından 1774'te bir Buharalıya satılmıştır (Barthold, 2004, s. 311; Efremov, 1811, s. 16). Buhara'ya geldikten sonra dönemin hükümdarı Danyal Biy Atalık’a (1759-1785) hediye edilen Efremov, askeri tecrübelerinden istifade edilmek üzere Atalık tarafından emirlik ordusuna yerleştirilmiş ve kısa zamanda yüksek bir makama ulaşmıştır. Ancak Buhara'da bulunduğu süre içerisinde daima firar etmenin yollarını arayan Efremov, nihayet bir hile ile Buhara'dan ayrılarak önce Margilan'a, sonra tüccar kılığında sırasıyla Kaşgar, Yarkend, Tibet ve Hindistan'a geçmiş ve buradan da bir yolunu bularak Ingiltere'ye, oradan da Rusya'ya geçebilmiştir. Farsça ve Asya dillerine hâkim olması dışişleri bakanlığına tercüman olarak atanmasına katkıda bulunmuştur (Efremov, 1811, s. 17-30). Efremov'un Buhara sarayındaki resmi konumunun da verdiği avantaj, seyyahın, dönemin Buhara'sı hakkında çok kıymetli bilgiler edinmesini sağlamıştır.

Efremov, Buhara'ya özel bir misyonla gelmediğinden olsa gerek, seyahat notlarında daha ziyade iyi bir şekilde gözlemlediği ülkenin, sosyal, kültürel, iktisadi ve coğrafi durumuna odaklanmış-

${ }^{16}$ Bkz. İstoriçeskie İzvestiya o Kirgiz-Kaysakah i Snoşeniyah Rossii s Sredneyu Aziyu so Vremeni Konçinı Abul-hayr Hana (1748-1765) (1853). (Soçinenie V. V. Velyaminova-Zernova), Ufa.

${ }^{17}$ Rus Çarlığı'nda 1773-75 yılları arasında meydana gelmiş ve devleti ciddi manada sıkıntıya sokmuş bir isyan hareketidir. II. Katerina zamanında gerçekleşen bu isyanın en önemli sebebi, uzun süren savaşlar sonucunda zaten zor şartlar altında yaşayan köylünün sırtına bindirilen ağır vergi yüküdür. İsyan hareketi Don Kazaklarından Emilyan Pugaçov'un, Yayık Nehri havalisindeki köylüleri etrafına toplamasıyla başlamış ve kısa zamanda büyümüştür. Kendisini Katerina'nın bertaraf ederek öldürttüğü bir önceki Rus çarı III. Petro olarak tanıtan Pugaçov, özellikle Yayık ve İtil havalisinde yaşayan Rus kazakları ve gayrı Rus unsurları çevresine toplamayı başarmış ve 25000 kişiyi geçen bir ordu meydana getirmiştir. Türk unsurlardan Başkurt ve Kazan Tatarlarının destek verdiği isyan hareketi, Rus subayların saraya sadık kalmaları, Pugaçov'in liderlik yönünün zayıflığı ve dış güçlerden yardım alınamaması (Osmanlı yöneticileri kurulmak istenen ittifakı değerlendirememişlerdir) gibi sebeplerden ötürü başarıya ulaşamamış, yaklaşık iki yıl sonra bastırılmıştır. İsyanın sonucunda Tatarlar ve Başkurtların durumu biraz zorlaşsa da, bir süre sonra durum değişmiş ve II. Katerina ülkedeki Müslüman ahaliyi kazanmak için, şiddetli tedbirlerin bazılarını yumuşatmıştır. Dahası, önceki dönemlerde yasaklanan cami ve medreselere izin vermiştir (Kurat, 1999, s. 283-285; Vernadsky, 2015, s. 215) 
tır. Fakat orduda da vazife alması dolayısıyla başta emirliğin askeri durumu olmak üzere, saray memuriyetleri hakkında da yine değerli bilgiler vermiştir. Bu durum o dönem için kaynak eksikliğinin söz konusu olduğu bu meselelerin aydınlatılması açısından önemlidir.

Buhara ülkesindeki tarım ve hayvancılık hakkında hatırı sayılır bilgiler veren Efremov, diğer gözlemciler gibi pamuk, ipek, kavun, karpuz ve üzüm üretiminin iyi durumda olduğuna değinmiştir. Ülkedeki hayvanlar hakkında verdiği bilgiler ise dikkate değerdir. Buhara'da bulunan atları yakından gözlemleyen seyyaha göre, bunlar Rus atlarına göre daha güzel ve ülkede oldukça boldur. Ancak Buhara atları taşıma amaçlı kullanılmaz. Taşıma ihtiyacı kuzeyden, Kazak coğrafyasından gelen atlarla sağlanmaktadır. Bölgede taşıma ve ticaret amacıyla kullanılan develerin varlığına değinen seyyah, büyük ve küçükbaş hayvanların da yaygın olduğunu söylemektedir (Efremov, 1811, s. 6166).

Efremov, Beneveni'nin aksine emirlik coğrafyasının altın ve gümüş madeni açısından oldukça fakir olduğunu vurgulamaktadır. Buna mukabil duyumlarına göre Hive'den Mangışlak’a uzanan dağların ise altın madeni açısından zengin olduğunu söyler. Altındaki bu eksiklik ülkeye giren İran, Çin, Hindistan ve Hollanda altınlarının eritilmesi ve Buhara parası olarak darp edilmesiyle giderilmektedir (Efremov, 1811, s. 70).

Seyyahın Buhara ülkesindeki demografik yapı, Özbeklerden başka farklı etnik unsurların yaşam tarzı ve kültürleri hakkında verdiği bilgiler de dikkate değer niteliktedir. Yemek konusunda Özbek pilavı ve yapılışı hakkında bilgi veren seyyah, Buharalıların sebzeden daha ziyade et ağılıklı beslendiğinden bahsetmektedir. Şeriat kanunlarının sert bir şekilde uygulandığı ve ceza sistemi çeşitli örneklerle anlatılmıştır. Özellikle zina, hırsızlık gibi suçlarda recm cezasının uygulanması söz konusudur (Efremov, 1811, s. 72-77).

Şehir mimarisi ve önemli yapılar hakkında genel bilgiler veren seyyah, özellikle taş binaların azlı̆̆ını ve neredeyse bütün yapılaşmanın kerpiçten olduğunu notlarına eklemiştir. Ayrıca yapıların bakımsızlıktan kaynaklanan bazı sorunlarına da değinmiştir. Buhara'ya gelen çoğu seyyah gibi o da içme suyu sağlamadaki yetersizlikten dolayı ciddi hastalıkların ülkede kol gezdiğini söylemektedir. Seyyah bizzat kendisi de rişta hastalığından muzdarip olmuştur (Efremov, 1811, s. 79-80). Buhara şehrinin nüfusu hakkında da bilgiler veren seyyaha göre şehirde 70000 (100000'den az, 50000'den fazla) civarında insan yaşamaktadır. Bunlara ülkeye ticaret için gelen halklar da dâhildir. Efremov'un Buhara şehri haricinde Semerkand hakkında verdiği bilgiler ise, bir zamanlar Türkistan'ın gözdesi olan bu şehrin 18. asırda ne denli gerilediğini gözler önüne sermektedir. İç karışıkıklar boyunca şehir sürekli fakirleşmiş ve şehirde neredeyse hiç medrese ve eğitim kurumu kalmamıştır. Şehirde 2000'e yakın hane bulunmakta olup, yaklaşık olarak da 5000 insan yaşamaktadır (Efremov, 1811, s. 95-96, 98-99).

Seyyahın emirlikteki medreseler ve buradaki eğitim hakkında vermiş olduğu bilgiler Türkistan'daki kültürel parlaklığın henüz sönmediğini göstermektedir. Nitekim bölgenin en iyi medreselerinin bulunduğu şehir olarak ifade edilen Buhara'ya İdil-Ural sahasından Tatar Türkleri başta olmak 
üzere, diğer ülkelerden Müslümanlar dini eğitim almak için gelmektedir ${ }^{18}$. Bunun yanı sıra Mangıt hanedanının yakın bir zamanda iktidara geldiği süre zarfında nakib, kadı, müftü, ahun, molla gibi din adamlarının yönetimde çok da etkili olmadıkları vurgulanır (Efremov, 1811, s. 82-83).

Ticaret konusunda bölgenin, konumundan dolayı büyük bir avantaja sahip olduğunu vurgulayan Efremov, Buharalıların iyi tüccarlar olduklarını; Hintliler, İranlılar, Ruslar, Hiveliler, Kazaklar ve Kalmuklarla ticari faaliyetlerde bulunulduğunu söylemektedir. Özellikle Hintlilerle yapılan ticarette, atlar karşılığında altın, gümüş, inci gibi değerli madenler elde edilmektedir. İran’a bağlı Merv ve Altıncami şehirleri ile yapılan ticaret oldukça canlıdır. Buralardan bıçak ve kılıç süslemek için firuze taşı alınmaktadır. Doğu Türkistan şehirleri Kaşgar ve Yarkend ile yapılan ticaret de önemlidir. Bu şehirlere kaftan gönderilir. Rusya ile yapılan ticarette ise meyve, pamuklu ve ipekli kumaşlar ihraç edilen ürünler olurken; şeker, çeşitli tuhafiye malzemeleri, ilaç ve balmumu ise ithal edilir (Efremov, 1811, s. 85-86). Bu ayrıntılar Mangıtlar devriyle birlikte ticarette bir toparlanma olduğunu göstermektedir.

Saray ve saray erkânından bahseden Efremov, yapay bir tepecik üzerinde kurulu sarayı oldukça mütevazı bulmaktadır. Han'ın haremi küçük olup bir eşi ve altı cariyesi vardır. Atalık'ın ise altı eşi ve altı cariyesi vardır. Han oldukça nadir görülmektedir (Efremov, 1811, s. 97). Buhara Emirliği'nin ordusu hakkında verilen bilgilerde ise, dönemin önemli askeri rütbeleri, askerlerin aldığı maaşın miktarı, ayrıca silah ve teçhizat hakkında detaya girilmiştir. Özellikle unvan ve makamlar hakkında verilen bilgiler, o dönem adına dikkate değerdir. Ordudaki rütbeliler arasında en önde gelen kişi

\footnotetext{
18 İdil-Ural Türklerinin dini eğitim almak üzere Türkistan'a yönelmeleri, Rusya'daki Ortodoks baskının zamanla azalmasıyla alakalıdır. Fakat özellikle 18. asrın ortalarında yoğunlaşan bu ilgi, Türkistan'daki gerilemeye paralel olarak başlayan kültürel durgunlukla birlikte giderek azalmıştır. Ticaretle zenginleşen Tatar burjuvazisi ise artık kendi merkezleri Kazan'a yatırım yaparak kültürel cazibeyi bu şehre çekmişlerdir. Ancak yine de Orta Çağ Türk-i̇slam medeniyetinin kültür merkezleri olan Maveraünnehr şehirleri, bu vasıflarını hemen kaybetmemiş, önemli şahsiyetlerin yetişmelerini sağlamıştır. Kazan Tatarının yenilikçi din adamı ve tarihçisi Şehabeddin Mercanî’nin fikirlerinin oluşumunda 1838-1849 yılları arasında bulunduğu Maveraünnehr medreseleri (Buhara ve Semerkand'da) ve âlimlerinin etkisi büyük olmuştur (Gömeç, 2003, s. 327; Kanlıdere, 2004, s. 169)
} 


\section{Selim Serkan ÜKTEN}

atalıktır $^{19}$. Bu unvan sahibi aynı zamanda ordunun başkomutanıdır. Atalıktan sonra gelen koşbegi20 ise iki bin veya üç bin kişinin komutanıdır. Tugsaba ise bin kişinin komutasından sorumludur. Tugsabadan sonra sırasıyla yüzbaşı, ellibaşı ve onbaşılar gelmektedir. Efremov'un verdiği bu bilgilerden Mangıtların, Nadir Şah'ın ordu düzenini, yani onluk sisteme dayanan teşkilatlanmayı örnek aldıkları anlaşılmaktadır. Silah ve teçhizat konusunda verilen bilgilere göre ise Buhara ordusunda fitilli tüfek, mızrak, kılıç ve top kullanılmaktadır. Ancak topların kalitesi Efremov'a göre zamanının gerisindedir (Efremov, 1811, s. 86-88, 97).

Efremov, 1786 'da görüp geçirdiklerini bir araya getirerek eserini yayımlamıştır. Kısa zamanda büyük bir ilgi gören eser, 1794 ve 1811 yıllarında tekrar neşredilmiştir. Çalışmamızda Efremov'un Buhara hakkında verdiği bilgiler için, Petr Kondırev tarafından kitaplaştırılan ve 1811'de Kazan'da yayımlanan eserden istifade edilmiştir ${ }^{21}$.

\subsection{T. Burnaşev:}

18. asırda Rusların Kazak coğrafyası ve Batı Türkistan vahasını kapsayan son elçilik faaliyeti 1794'te gerçekleşmiştir. Özellikle İngilizlerin Afrika'da keşif faaliyetlerini hızlandırdığı süreci yakından takip eden Çariçe II. Katerina (1762-1796), yeni Orta Asya görevi için maden görevlisi T. Burnaşev ve Rus ordusunda görevli A. S. Beznosikov'u görevlendirmiştir. 1794'te Omsk'tan, General Ştrandman'ın nezaretinde yola çıkan heyet, Orenburg-Kızılkum Çölü hattı boyunca bir rota çizerek hareket etmiş ve 1795 yılında Buhara şehrini görebilmiştir. Yaklaşık iki ay süren yolcukta, elçilik

\footnotetext{
${ }^{19}$ Efremov'un burada bahsettiği şahsiyet, Danyal Biy Atalık'tır. O da ağabeyi Muhammed Rahim Biy gibi Çingizli geleneğini hemen göz ardı etmeyerek Astrahanlıların tahtta oturma geleneğini sürdürmüş ve sülalesinin, Astrahanlıların son dönemlerinde ele geçirdiği Buhara devlet hiyerarşisinin handan sonra en üst makamı olan atalık unvanını kullanmaya devam etmiştir. Mangıtların Astrahanlıları saraydan tamamen uzaklaştırması ve kendilerini emir ilan etmeleri ise Danyal Biy'in oğlu Şah Murad zamanında gerçekleşecektir.

20 Buhara Hanlığı devlet teşkilatlanmasında, Astrahanlıların son hükümdarı Ebulfeyz Han döneminden itibaren üst düzey makamlar arasında yerini alan koşbegi (ordugâhın emiri, komutanı manasındadır), Mangıtlar devrinde atalık unvanının artık onursal bir makam haline dönüşmesiyle hanlık/emirlik makamından sonra devletteki en yüksek makam haline gelmiştir. Buhara Hanlığı tarihi boyunca başta askeri görevler olmak üzere pek çok idari işi ele alan koşbegi makamı, Mangıtlar devri kaynaklarından anlaşıldığına göre, söz konusu hanedan döneminde idari erki, iç ve dış işlerini ve şehir yöneticiliği gibi yetkileri elinde toplamıştır bkz. (Ükten, 2015, s. 89-92).

${ }^{21}$ Bkz. F. Efremov. (1811). Stranstvovanie Filippa Efremova v Kirgizskoy Stepi, Buharii, Hive, Persii, Tibete $i$ Indii $i$ Vozvraşenie ego Ottuda Çrez Angliyu v Rossiyu, (red.: P. Kondıreva), Kazan.
} 
heyetine Kazak ileri geleni Yemankaya ve sekiz Tatar tacir²2 de katılmıştır (Burnaşev, 1918, s. 3845).

Burnaşev'in Buhara'ya geldiği tarihte tahtta Danyal Biy'in oğlu Şah Murad (1785-1800) bulunmaktadır. Şehre geldikten iki gün sonra, Buhara hükümdarının memurlarınca ziyaret edilen elçi, onlara gelme amaçlarının Rus hükümeti tarafından hazırlanan mektupları Şah Murad ve Buhara'ya bağlı bölge yöneticilerine iletmek olduğunu bildirmiştir. Fakat Buharalıların, Şah Murad dururken Hocent, Taşkent, Türkistan (Yesi) gibi bölge yöneticilerine mektup gönderilmesine şüpheyle yaklaşımı tartışmalara yol açsa da, Burnaşev'in, Şah Murad'ın sarayına teşrifi nihayet gerçekleşmiştir (Burnaşev, 1918, s. 49-55). Teşrifat sırasında doğrudan hükümdarın huzuruna çıkarılmayan elçiye, hayati tehlikelerinin bulunduğu öne sürülerek Taşkent'e gitmesi için izin verilmemiştir. Elbette casusluk faaliyetinde bulunacağından şüphelenilen elçinin, Taşkent'e ulaşmaması için bir bahane olduğu anlaşılan bu yaptıım, Burnaşev'in iki aylık süre zarfında misafir olacağı Buhara'da serbestçe dolaşma imkânı bulmasına olanak sağlamıştır (Burnaşev, 1918, s. 59).

Burnaşev ve beraberindekiler Buhara Emirliği'nde bulunduğu süre zarfında ülkenin coğrafi yapısından yönetim mekanizması, toplum yapısı ve iktisadi hayatına kadar pek çok konuda gözlemlerde bulunmuşlardır. Elçiliğin raporlarında Buhara'da yaşayan halklar hakkında verilen bilgiler dikkat çekicidir. Buhara'da, Özbek, Fars, Kırgız, Afgan, Lezgi, Ermeni ve Yahudi halklarının yaşadıkları bildirilirken, özellikle o dönemin Buhara Yahudileri hakkında önemli bilgiler sunulmuştur. Verilen bilgilere göre Ermeniler ve Yahudiler gayrimüslim tebaa olarak dini vecibelerini serbestçe yerine getirebilmektedir. İpek boyama ve ipekten elde edilen çeşitli kumaşları üretebilen Yahudiler genel olarak zengindirler, fakat 50 yaşlarına kadar yıllık 35 tenge (gümüş) de vergi ödemek zorundadırlar. Ticaretin Buhara şehri için önemli bir ayrıntı olduğunu bildiren Burnaşev, bu sebepten dolayı Rus, Tatar, Gürcü ve Ermenilerin şehirde sürekli bulunduklarını ve şehrin bu sebepten dolayı kalabalık olduğunu bildirir. Büyük ihtimalle ülkeye henüz yerleşmiş Ermeniler, ticaretten dolayı Buhara'da ikamet etmeyi tercih etmişlerdir (Burnaşev, 1918, s. 65-68). Anlaşılan ticarette Mangıtlarla başla-

\footnotetext{
22 II. Katerina zamanında Rusya'daki Müslümanlara verilen haklar, bu dönemden itibaren İdil-Ural Tatarlarının ticarette de serbestçe hareket etmelerini ve zenginleşmelerini sağlamıştır. Bunun sonucunda Tatarlar, Rusya'nın özellikle de Orta Asya ile olan ticaretinde ön plana çıkmışlardır. Tatarların Müslüman olmaları ve Türkistan halkıyla aynı dili konuşmaları bunda en önemli etkenlerden biridir. Diğer taraftan Türkistan toplumunun kendilerine karşı önyargılarının farkında olan Ruslar da, Türkistan ticaretinde Tatarları vasıta olarak kullanarak, 16. asırdan beri hayalini kurduğu Uzakdoğu'ya kadar varacak olan ticaret hattını canlandırmayı düşünmüşlerdir. Böylece Tatar toplumu 18. asrın ikinci yarısından itibaren Rus kampanyalarının, şirketlerinin ortakları, tercümanları veya işbirlikçileri haline gelmişler, Türkistan ile kurulacak diyalogda baş aracılardan biri olmuşlardır (bu durum 19. asrın ortalarında Rusların Türkistan'ı işgal ederek kendisine bağlamasıyla sona ermiştir, zira söz konusu meselede artık Tatarlara ihtiyaç kalmamıştır) (Gündoğdu, 2014, s. 1145-1146). Bu durumda konumuz olan diplomatik seyahatlerde de Tatarların varlığına rastlanması doğaldır.
} 
yan gelişim, iç düzenin giderek sağlandığı Şah Murad zamanında daha da hızlanmıştır. Şehirdeki ibadethanelerin nüfusa göre fazlaca olması elçinin dikkatinden kaçmamıştır. Özellikle medreselerin her yaşta vatandaşa eğitim verdiği, fakirlerden ise belli bir ücret alınmadığı vurgulanır. Şehirde birden fazla çarşı bulunduğu aktarıırken, bunlardan birinde Orta Asya'da önemli bir ayrıntı olan kölelerin satıldığından bahsedilmektedir (Burnaşev, 1918, s. 72,75).

Bir maden görevlisi olması sebebiyle Buhara ülkesindeki madenleri dikkatle inceleyen Burnaşev, ülkenin madencilik konusunda ne derece geride kaldığını gözler önüne sermektedir. Zira ona göre ülke, altın ve gümüş madeni açısından zengindir, fakat bu madenler çıkarılıp işlenmek yerine, bu ihtiyaç Hindistan, İran ve Çin'den karşılanmaktadır. Diğer taraftan sülfürik asit, güherçile, kurşun, kükürt ise işlenebilmektedir. Burnaşev, Buhara'nın daha ziyade tarımda ön planda olduğunu ve tarımın başarılı bir şekilde yapılabildiğini vurgular ki, bunun sebebini kuraklı̆g rağmen su kanallarının varlığına bağlarlar. Bu da elbette ki Amu Derya Nehri ve kollarının Buhara ülkesinden geçiyor olmasındandır. Burnaşev diğer seyyahların da üzerinde durduğu üzere ülkede pamuk, kavun, karpuz ve ipek üretiminin fazla olduğunu gözlemlemiştir. Şehirde daha ziyade ticaret ve zanaatkârlık ön plana çıkarken, kırsal ise tarım ve bahçecilikle geçimini sürdürmektedir (Burnaşev, 1918, s. 75-78).

Buhara toplumunu yakından inceleyen elçi, her ne kadar şeriat kurallarına riayet etmenin devlet açısından önemli bir husus olduğunu vurgulasa da, halkta ciddi bir şeriat savunuculuğu olmadığını yazmıştır. Burnaşev, Buharalıların bu konuda Sibirya Tatarlarından bile daha az şeriat kurallarına uyduğunu ve başka dinde olanlara herhangi bir baskı yapılmadığını vurgular. Şehirde yaşayan halkların karakterleri, fiziksel yapıları analiz edilirken, Buhara'nın yerli ahalisinin (Taciklerin) biraz kibirli ve diğer halkları küçümsedikleri, bununla birlikte halifelik makamından olsa gerek sadece Anadolu Türklerine saygı duydukları elçinin dikkatini çeken ayrıntılardandır (Burnaşev, 1918, s. 8487). Burnaşev de Buhara'ya gelmiş daha önceki seyyahlar gibi, Buharalıların temiz su kullanımı konusundaki özensizliklerine dikkat çekmektedir. Özellikle içme suyu konusunda halk Buhara'da bulunan 30'a yakın havuzu, yani durgun suyu tercih etmektedir ve rişta hastalı̆̆ı bu sudan insanlara geçmektedir. Diğer seyyahların da haber verdiği bu hastalıkla alakalı biraz detay vermek gerekirse, kılımsı solucanlar vücuda suyoluyla girerek deri altında yaşamını sürdürürler. Tedavisi oldukça ilkel yöntemlerle yapılan bu hastalığın nasıl bulaştığı bilinmesine rağmen, halk bunu pek de önemsememektedir. Suyu nehirden alan bilinçli kesim ise bu hastalıktan muzdarip değildir. Ülkede doktor bulunmadığı ve hastalıkların tedavi yöntemi olarak hacamat tedavisinin yaygın olduğu da Burnaşev'in raporlarında sabittir (Burnaşev, 1918, s. 92-95).

Elçinin Buhara devlet yönetimi hakkında verdiği ayrıntılar da dönem adına dikkate değerdir. Raporlara göre Emir Şah Murad, toplumsal kuralların dışında hareket edenlere karşı kanunda oldukça sert tedbirler almaktadır, fakat halk yine de gevşek tutumundan vazgeçmemektedir. Ülkede başta hırsızık olmak üzere suç oranı yüksektir. Bunun neticesinde kolluk güçleri oldukça sıkı, cezalar da başta idam olmak üzere ağırdır. Burnaşev'in gözlemlerine göre Buhara'da şehir yöneticilerine tugsaba, taşra yöneticilerine ise aksakal denilmektedir. Tugsaba hükümdar tarafından seçilirken, 
aksakalı halk kendisi seçmektedir. Vergiler hususunda verilen ayrıntılardan, nakdi ödemelerin ve savaş zamanı alınan özel verginin halktan sıkı tedbirlerle alındığı anlaşılmaktadır (Burnaşev, 1918, s. 97-100).

Buhara ordusu hakkında verilen bilgiler, daha önceki seyyahların verdiği bilgilerden farklı değildir. Genel olarak geri kalmış bir ordu niteliği taşıyan Buhara Emirliği ordusunda, bir asker elbisesinin normal bir insanın elbisesinden farkı olmadığı, ok, yay, mızrak gibi kadim silahların varlığının devam ettiği, savunma teçhizatı olarak kalkanların bazen hala deriden imal edildiği göze çarpmaktadır. Savaş sırasında erzak oldukça azdır. Ateşli silahlar konusunda Buharalıların toplarının olduğu, fakat bunların İran işi oldukları vurgulanır. Daha önce Grigoryev ve Efremov'un topçuluk hakkında verdiği bilgilerden de anlaşılacağı üzere bu toplar, emirliğin kurucusu Muhammed Rahim Biy tarafından İran'dan getirilme toplardır. Toplar kaba yapılı olup büyük zorluklarla hareket ettirilmekte ve ateşlenmekte, top gülleleri ve tüfek mermileri ise Buharalılar tarafından dökülebilmektedir (Burnaşev, 1918, s. 103). Yine de bu bile topçuluk sanatında geçmiş yıllara göre bir kıpırdanma olduğunu göstermektedir. Burnaşev son olarak Şah Murad'ın 1795'te gerçekleştirdiği İran seferinden bahsetmektedir.

Burnaşev'in elçilik görevi boyunca yapmış olduğu gözlemler sonucunda hazırladığı raporlar, G. Spasskiy tarafından bir araya getirilerek, Sibirskiy Vestnik (Sibirya Habercisi) adlı bir dergide yayımlanmıştır ${ }^{23}$.

\section{Sonuç}

Tarih boyunca seyyahların uğramış olduğu Batı Türkistan coğrafyası, Rusların 16. asırdan itibaren giderek güçlenmesiyle, bu devlet tarafından yakından takip edilmiştir. Bundan ötürü 17. asrın başlarından itibaren bölgeyi daha iyi tanımak isteyen Ruslar, Türkistan'ın merkez devleti durumunda olan ve 1500-1868 yılları arasında bağımsız bir şekilde varlığını sürdüren Buhara Hanlığı'na diplomatik temaslarda bulunmak üzere pek çok resmi devlet görevlisi göndermiştir. Söz konusu devlet görevlilerinin raporları ve bunun yanı sıra bölgeye başka sebeplerden dolayı gelmiş seyyahların tutmuş olduğu notlar, bu noktada Buhara Devleti ve Türkistan coğrafyası tarihi adına çok önemli birer tarihi veri haline gelmiştir.

Diplomatik geziler Rus tarafından bakıldığında sadece siyasi ilişkileri artırmak, ticaret yolları aramak veya Rus esirleri kurtarmak gibi sebeplerle gerçekleştiriliyor gibi görünse de, esasında rakibi tanımaya yönelik girişimlerden başka bir şey değillerdir. Zira ortaya çıkan raporlar incelendiğinde, görevlilerin başka talimatlar aldıkları da anlaşılmaktadır. Özellikle devletin yönetim mekanizması, gücü, askeriyesi ve tabi kaynakları farklı dönemlerde ülkeyi ziyaret eden görevlilerce dikkatle incelenmiştir. Resmi görevliler dışında, yolları çeşitli sebeplerden dolayı Buhara Hanlığı'na düşmüş olan seyyahların notları da, hanlık adına verdiği detaylarla dikkat çekmektedir. Seyahat notlarında veri-

\footnotetext{
${ }^{23}$ Bkz. T. Burnaşev. (1918). Puteşestvie ot Sibirskoy Linii do Goroda Buharı v 1794 i Obratno v 1795 godu, (red.: G. Sapisskiy). Sibirskiy Vestnik (çast' 2-3). S. Peterburg, s. 37-110.
} 
len bilgilerin büyük bir bölümü, Buhara'nın yerli kaynaklarınca da doğrulanmaktadır. Bunun yanı sıra ortaya çıkan raporlar veya notlar yerli kaynakların vermediği, bazen de eksik kaldığı ince detayların öğrenilebilmesi açısından büyük bir önemi haizdir. Seyahatlerin belirli aralıklarla yapılmış olması Orta Asya'daki değişim sürecinin iyi algılanabilmesi açısından da dikkat çekicidir. Özellikle hanlıklar arasındaki siyasi ilişkiler, feodal çekişmeler veya ekonomik, sosyal ve kültürel hayattaki inişler, çıkışlar ve değişimler, kaynakların bütünü değerlendirildiğinde göze çarpmaktadır. Bu noktada özellikle 18. asırdaki seyyahların gözlemleri, hanlığın başta siyasi olmak üzere, ekonomik, sosyal ve kültürel alanda ciddi bir gerileme halinde olduğunu ve olası bir işgale karşı kendini koruyamayacağını gözler önüne sermektedir. Seyahat notları incelendiğinde verilen bilgilerde bazı yanlışıılar veya abartılar olduğuna da dikkat çekmek gerekir. Batılının gözünden köhnemişlik ve geri kalmışlık, Türkistan toplumunu biraz da küçümseyen ifadelerle sunulmuştur ki, bunların önyargılardan kaynaklandığını anlamak zor değildir.

Rusların özellikle 17. asırda gerçekleştirdikleri diplomatik faaliyetlerde, Rus esirleri yeterince kurtaramadıkları ve yeni ticari yollar keşfetme meselesinde Türkistan'daki asayiş sorunlarından dolayı amaçlarına tam olarak ulaşamadıkları görülmektedir. Fakat belirli dönemlerde ortaya çıkan seyahat raporları Rus Çarlığı'na, rakiplerinin uzun bir periyotta ne aşamada ve ne durumda olduklarını kavramaları açısından muazzam bir katkı sağlamıştır. Belki de oluşturulan raporların bütününde yer alan bilgiler, Türkistan'ı işgali ve sömürge haline getirmesi sürecinde Rusya'ya katkıda bulunmuştur. Buhara Hanlığı tarafında ise gelen elçilik heyetlerine hürmetkâr davranılmakla birlikte, şüphe ile de yaklaşılmıştır. Fakat casusluk faaliyetlerine karşı ciddi bir önlemin alınmadığı da görülür. Özellikle Çar Petro'nun üzerinde durduğu hanlıkta bulunan hanedan üyelerini veya feodal güçleri birbirine düşürme politikasının, Buhara devlet erkânınca fark edildiğine Beneveni'nin serüveninde şahit olmaktayız. Fakat buna karşı ciddi bir önlem alınmadığı da ortadadır. Maalesef Buhara veya Hive'nin ileri gelenleri, bu görevlilerin topraklarında neden bulunduğunu anlamak veya buna karşı bir önlem almak yerine, elçilerin beraberinde getirdiği cezbedici hediyelere dikkat kesilmişlerdir. Bu durum yönetim mekanizmasında yaşanan yozlaşma ve geri kalmışlı̆̆ gözler önüne seren ayrıntılardan biridir.

Netice itibariyle gerek devlet görevlileri gerekse de diğer seyyahlar tarafından meydana getirilen gezi raporları ve notları, Buhara Özbek Hanlığı ve Türkistan tarihi araştırmalarında, siyasi, askeri, kültür ve şehir tarihi çalışmaları başta olmak üzere pek çok alanda, araştırmacılara değerli bilgiler sunmaktadır.

\section{Kaynaklar}

Alpargu, Mehmet. (2002). Türkistan Hanlıkları, Türkler (8. Cilt), Ankara: Yeni Türkiye, ss. 557-605.

Barthold, V. V. (2004). Rusya ve Avrupa'da Oryantalizm (Çeviren: Kaya Bayraktar, Ayşe Mera), İstanbul: Küre Yayınları. 
Beneveni, F. (1986). Poslannik Petra I. na Vostoke Posol'stvo Florio Beneveni v Persiyu i Buharu v 1718-1725 godah, Moskva: Glavnaya Redakstiya Vostoçnoy Literaturı Izdatel'stva "Nauka”.

Burnaşev, T. (1918). Puteşestvie ot Sibirskoy Linii do Goroda Buharı v 1794 i Obratno v 1795 godu, (red.: G. Sapisskiy). Sibirskiy Vestnik (çast' 2-3). S. Peterburg, ss. 37-110.

Clavijo, Ruy Gonzalez. (2016). Timur Devrinde Kadis'ten Semerkand'a Seyahat (Çeviren: Ömer Rıza Doğrul), İstanbul: Köprü Kitapları.

D’ohsson, A. C. M. (2014). Moğol Tarihi, (Yay. Haz.: Ekrem Kalan), İstanbul: IQ Kültür Sanat Yayıncilık.

Efremov, F. (1811). Stranstvovanie Filippa Efremova v Kirgizskoy Stepi, Buharii, Hive, Persii, Tibete i Indii i Vozvraşenie ego Ottuda Çrez Angliyu v Rossiyu, (red.: P. Kondıreva), Kazan.

Golden, P. (2014). Dünya Tarihinde Orta Asya, (Çeviren: Yahya Kemal Taştan), İstanbul: Ötüken Neşriyat.

Gömeç, Saadettin. (2003). Türk Cumhuriyetleri ve Toplulukları Tarihi, Ankara: Akçağ Yayınları.

Gündoğdu, Abdullah. (2014). Türk Dünyasında Milli Egemenlik Fikrinin Gelişimi, Belgi Dergisi, 8(2), ss. 1139-1149.

İstoriçeskie İzvestiya o Kirgiz-Kaysakah i Snoşeniyah Rossii s Sredneyu Aziyu so Vremeni Konçinı Abul-hayr Hana (1748-1765) (1853). (Soçinenie V. V. Velyaminova-Zernova), Ufa.

Jenkinson, A. (1886). Early Voyages and Travels to Russia and Persia (Vol. I). (Edited by. E. Delmar Morgan, C. H. Coote), New York.

Kanlıdere, Ahmet. (2004). Mercani, Diyanet Vakfı Islam Ansiklopedisi (Cilt 29), Ankara: Türkiye Diyanet Vakfı, ss. 169-172.

Kurat, Akdes Nimet. (1999). Rusya Tarihi. Ankara: Türk Tarih Kurumu.

Marco Polo'nun Geziler Kitabı (2015). (Çeviren: Ömer Güngören), İstanbul: Yol Yayınclık.

Mirza Badi Divan. (1981). Madjma Al-Arkam (Predpisaniya Fiska): Priemi Dokumentaçii v. Buhare XVIII. v., (Faksimile Rukopisi Vvedenie, Perevod, Primeçaniya i Prilojeniya A. B. Vildanovoy), Moskva: Izdatel'stvo Nauka Glavnaya Redakçiya Vostoçnoy Literaturı.

Nakaz Borisu i Semenu Pazuhinım, Poslannım v Buharu, Belh i Yurgenç 1669 (1894). (Red.: A. N. Truvorova), Ruskaya istoriçeskaya Biblioteka, 15, S. Peterburg: Arheografiçeskoy Kommissii, ss. 1-91.

Plano Carpini'nin Moğolistan Seyahatnamesi (1245-1247) (2015). (Hazırlayan: Engin Ayan), Ankara: Gece Kitaplığı Yayınları.

Ruysbroeckli Willem. (2010). Mengü Han'ın Sarayına Yolculuk (1253-1255) (Çeviren: Zülal Kılıç), İstanbul: Kitap Yayınevi. 
Sbornik Knyazya Hilkova (1879). S. Peterburg, s. 388-439.

Sela, Ron. (2013). Seventeenth-Century Russian Diplomatic Mission to Central Asia, (edited by Nile Green), Writing Travel in Central Asian History, Bloomington and Indianapolis: Indiana University Press, ss. 69-88.

Togan, Zeki Velidi. (1942). Bugünkü Türkili (Türkistan) ve Yakın Tarihi (Cilt 1). İstanbul: Arkadaş, ibrahim Horoz ve Güven Basımevleri.

Togan, Zeki Velidi. (1969). Tarihte Usul, İstanbul: Edebiyat Fakültesi Basımevi.

Türker, Özgür \& Ükten, S. Serkan. (2014). Haçlılar, Moğollar ve Ortadoğu'da Haçlı-Moğol Münasebetleri, Ankara Üniversitesi Dil ve Tarih Coğrafya Fakültesi Dergisi, 54(1), ss. 319-344.

Ükten, Selim Serkan. (2015). Buhara Hanlığı'nın Askeri Teşkilatı (1500-1868), Yayımlanmamış Doktora Tezi, Ankara: Ankara Üniversitesi Sosyal Bilimler Enstitüsü.

Ükten, Selim Serkan. (2017). Bölgeselleşme ve Feodal Çekişmeler Kıskacında Buhara Hanlığı'nın Çöküş Süreci, (Editör: Alparslan Demir). Dede Korkut'un Izinde 30 Yıl içinde. Ankara: Gece Kitaplığı, ss. 65-94.

Vernadsky, George. (2015). Rusya Tarihi (Çeviren: Doğukan Mızrak, Egemen Mızrak), İstanbul: Selenge Yayınları. 